Review

\title{
Perovskite Solar Cells for BIPV Application: A Review
}

\author{
Anurag Roy $\mathbb{D}^{\mathbb{D}}$, Aritra Ghosh $* \mathbb{D}$, Shubhranshu Bhandari, Senthilarasu Sundaram $\mathbb{D}$ and \\ Tapas K. Mallick (D)
}

Environment and Sustainability Institute, University of Exeter, Penryn Campus, Cornwall TR10 9FE, UK; a.roy30@exeter.ac.uk (A.R.); sb964@exeter.ac.uk (S.B.); s.sundaram@exeter.ac.uk (S.S.); t.k.mallick@exeter.ac.uk (T.K.M.)

* Correspondence: a.ghosh@exeter.ac.uk

Received: 14 May 2020; Accepted: 10 July 2020; Published: 13 July 2020

\begin{abstract}
The rapid efficiency enhancement of perovskite solar cells (PSCs) make it a promising photovoltaic (PV) research, which has now drawn attention from industries and government organizations to invest for further development of PSC technology. PSC technology continuously develops into new and improved results. However, stability, toxicity, cost, material production and fabrication become the significant factors, which limits the expansion of PSCs. PSCs integration into a building in the form of building-integrated photovoltaic (BIPV) is one of the most holistic approaches to exploit it as a next-generation PV technology. Integration of high efficiency and semi-transparent PSC in BIPV is still not a well-established area. The purpose of this review is to get an overview of the relative scope of PSCs integration in the BIPV sector. This review demonstrates the benevolence of PSCs by stimulating energy conversion and its perspective and gradual evolution in terms of photovoltaic applications to address the challenge of increasing energy demand and their environmental impacts for BIPV adaptation. Understanding the critical impact regarding the materials and devices established portfolio for PSC integration BIPV are also discussed. In addition to highlighting the apparent advantages of using PSCs in terms of their demand, perspective and the limitations, challenges, new strategies of modification and relative scopes are also addressed in this review.
\end{abstract}

Keywords: renewable energy; perovskite solar cells; BIPV; semi-transparent; challenges

\section{Introduction}

Currently, building sector consumes $40 \%$ energy globally, which is expected to reach double or triple by 2050 because of population growth, changes of household size with improved electrical and cooking appliances, increasing levels of wealth and lifestyle changes at the global level [1-6]. In addition, this consumed building energy is responsible for emitting $40 \%$ of total carbon dioxide. The global emission is further expected to be $50 \%$ by 2050 if the current trend of energy consumption occurs [7-11]. Hence, replacement of building energy generation from fossil fuel, coal-based power plant to renewable energy sources is highly demanding. Photovoltaic (PV) power generation can displace fossil fuel-generated energy. The installed PV capacity surpassed 500 GW already in worldwide, and another $500 \mathrm{GW}$ installation is expected by 2023 [12]. However, PV generated power has low-density power supply compared to other renewable sources. Moreover, for large scale PV plant needs a large land area while transmission and distribution power losses are also very high. Hence, PV technology manifests potential opportunism in building architecture. The integration of PV in a building is known as building-integrated PV (BIPV), where PV replaces the traditional building envelopes such as window, roof, wall and offset building construction cost. At the same time, 
these new BIPV envelopes generate power and also protect the building interior from harsh external ambient [6,13-16]. Semitransparency or transparent nature is the precondition for BIPV envelopes as they are not only responsible for producing the benevolent power but also controls the net building energy consumption by offering suitable indoor ambient. Semi-transparent or transparent BIPV allow sufficient daylight, which reduces lighting energy demand and also controls heat loss and gain, which, in turn, reduce the heating and cooling load demand [17]. Although buildings have a strong potential of reducing their energy consumption and greenhouse gas emissions; the main challenge is to achieve this objective without compromising thermal comfort needs [18-20].

First-generation cost-effective, crystalline silicon for BIPV application needs space between cells to create semitransparency [21,22]. While second-generation thin film [23-25] and third-generation [26] emerging perovskite solar cells (PSCs) [27], dye-sensitized solar cells (DSSCs) [28], quantum dot solar cells (QDSSC) and organic-polymer solar cells [29] types possess semitransparency by tuning their corresponding cell thickness.

The photosynthesis process inspired the fundamental novelty of the third-generation PV concepts in the way of assembling the cell architecture, which allows easy and cost-effective processing to generate power from effective sunlight absorption [30]. Among the third generation PV system, PSCs are the most efficient technology that promises a cheaper and accessible fabrication route to produce more efficient photo-conversion efficiency (PCE). The perovskite materials satisfy almost all the requirements to achieve the best performance, as listed in Table 1.

Table 1. Summarized requirements for the best-performance photovoltaic (PV) applications in terms of materials and properties categories.

\begin{tabular}{|c|c|c|}
\hline \multicolumn{2}{|c|}{ Categories } & Requirement \\
\hline & 1 & Suitable bandgap matching the solar spectrum \\
\hline & 2 & Strong absorption coefficient \\
\hline \multirow[t]{6}{*}{ Properties } & 3 & Excellent and balanced carrier mobility \\
\hline & 4 & Defect tolerant \\
\hline & 5 & Ambipolar dopability \\
\hline & 6 & Long carrier lifetime and diffusion length \\
\hline & 7 & Reasonably low exciton binding \\
\hline & 1 & Earth-abundant/low cost \\
\hline \multirow[t]{3}{*}{ Materials } & 2 & Nontoxic \\
\hline & 3 & Long-term stability \\
\hline & 4 & High performance \\
\hline
\end{tabular}

In a typical PSC, the perovskite absorber layer is sandwiched between the electron and hole transport layer (ETL and HTL). Generally, the ETL deposits on a fluorine-based tin oxide (FTO)-based glass followed by the perovskite layer and HTL. Finally, a back contact introduces on the top of the HTL and thus a complete cell form. The sequential layers of a typical PSC are schematically described in Figure 1. Briefly, PSCs show a photovoltaic phenomenon when exposed to light, consequently producing photovoltage and photocurrent.

This kind of cell structure benefits for a high collection efficiency and low recombination of carriers, which are indispensable to realize a high conversion efficiency. Compared to other solar technology, PSC reacts to different wavelengths of light. This is due to the structure of the cells, which enables electrons to travel through various interfacial layers [31,32]. As a result, they can convert a proportionately higher amount of sunlight into electricity. Thus, it is required to mobilize the material quality of the perovskite absorber by enhancing their charge carrier and reduce the defect density. Despite the material quality improvement, the layer thickness adjustment is also a possible way to 
enhance cell performance. Maximum light trapping can provide mutual benefits for both the optical and electrical properties of the PSCs.

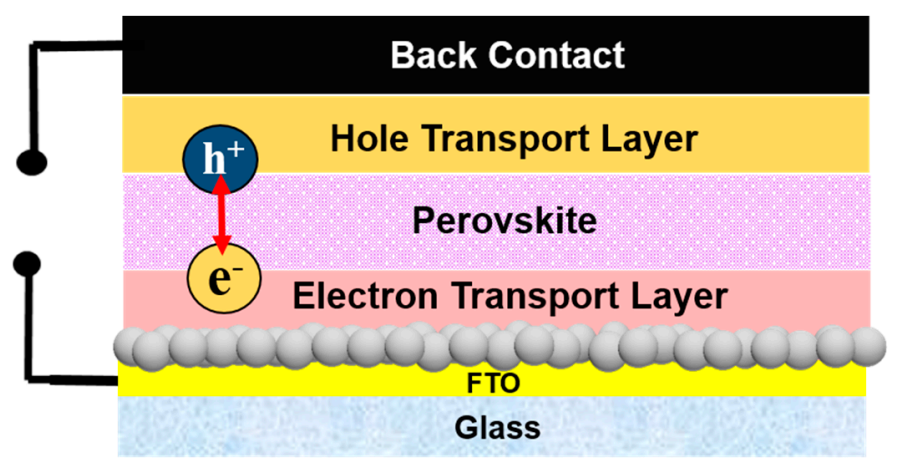

Figure 1. Schematic configuration of a typical perovskite solar cell.

To date, the number of publications on PSCs exceeded almost 17,726 according to the web of science while searching the keyword of "perovskite solar." Among them, 1143 publications were related to review articles [33]. Not only that, but most of the article also comes under the category of materials science multidisciplinary $(10,865)$, dealing with (1) emergence of perovskite solar cells, (2) fundamental relation with optoelectronics, ion mobility properties, (3) recombination effect, (4) theoretical studies to achieve high efficiency, (5) defect and interfacial related studies, (6) device architecture such as mesoscopic, planar, inverted, hole-transport material free tandem, etc., (7) stability and scalability related gripping topics [34-37]. Around 2554 publications are available including 865 proceeding papers and 150 review articles according to the web of science by searching the keyword "building-integrated photovoltaic". Nevertheless, interestingly, searching by the keywords "building-integrated photovoltaic perovskite solar" indicates only 37 articles, 9 reviews and 3 proceeding papers as per web of science. The status of the publications lists as gathered from the web of science thus highlights the adequate requirement of more research-based PSCs integration in BIPV (Figure 2).

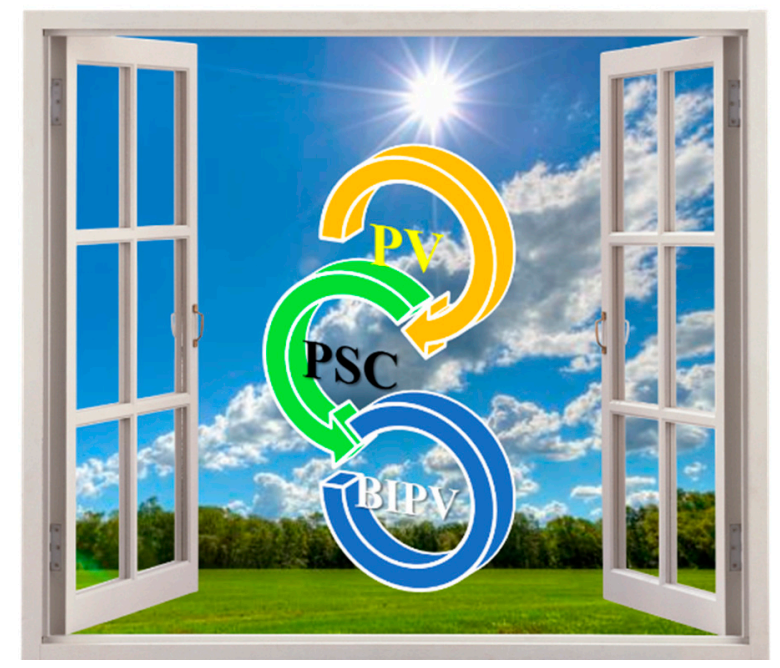

Figure 2. Schematic representation of the theme of this review represents perovskite solar cells integration to building-integrated photovoltaic (BIPV).

In this review, we have put great emphasis on the potentiality of PSCs integration for BIPV application through its appearance as an emerging PV technology to futuristic employment in BIPV application. A general phenomenon and the importance of the review are recapitulated in Section 1. Next, Section 2 illustrates the efficiency evaluation of PSCs as a breakthrough trendsetter in PV Afterwards; Section 3 highlights the difficulties associated with PSCs, mainly stability and toxicity. 
Then, Section 4 addresses on the PV technological aspects of PSCs includes transparency and efficiency tradeoff and up-scaling status. Then Section 5 discusses the advancement of PSCs integration in BIPV. This includes recent trends of PSCs in BIPV includes lightweight, solar paint techniques and zero-energy building conceptualization for sustainable BIPV adaptation. Next, Section 6 describes the future scope of PSCs integration in BIPV, followed by a constructive discussion in Section 7. Finally, the review is summarized with the concluding remarks in Section 8.

\section{Performance Trends Evaluation of PSC}

PSCs has become one of the hot spots owing to its dramatic development in efficiency levels and thus extensively studied in recent years [38-40]. The organic-inorganic perovskite material such as $\mathrm{CH}_{3} \mathrm{NH}_{3} \mathrm{PbI}_{3}\left(\mathrm{MAPbI}_{3}\right)$ and $\mathrm{CH}_{3} \mathrm{NH}_{3} \mathrm{PbBr}_{3}$ was successfully applied to first DSSCs as a promising alternative to the conventional molecular dyes. However, its instability in the liquid electrolyte seemed to put an obstacle for further development of higher efficiency [41]. Research activities on PSC were swiftly increased since the first reported solid-state PSC in 2012, having PCE of 9.7\% [42]. After this breakthrough, in the following years, the investigation of PSCs became gradually dominant in PV research. Eventually, the efficiency of PSCs was enhanced to $22.1 \%$ in early 2016 [43]. PSCs have achieved an efficiency of $>23 \%$ in just a few years. While writing this review article, the highest certified PCE reached 25.2\%, confirmed by the National Renewable Energy Laboratory [44]. However, the solution processing fabrication routes of perovskite resulted in its crystallization, defect passivation, which influences the interfacial optoelectronic properties. Therefore, the employment of various additive-assisted strategies for interface optimization can escalate the performance of a PSC. Table 2 highlights the recorded significant PCE of various PSCs in consecutive years in terms of their perovskite absorber modification and implementation of various device fabrication strategies in order to achieve the best performance.

Table 2. Significant performance achievement of experimental planner structure-based perovskite solar cells (PSCs) in consecutive years *.

\begin{tabular}{|c|c|c|c|c|}
\hline Perovskite Sensitizer & Device Assembly & PCE (\%) & Year & Reference \\
\hline $\mathrm{MAPbI}_{3}$ & $\mathrm{TiO}_{2} / \mathrm{CH}_{3} \mathrm{NH}_{3} \mathrm{PbI}_{3} /$ Electrolyte solution/Pt-FTO & 3.8 & 2009 & [42] \\
\hline $\mathrm{MAPbI}_{3}$ & $\mathrm{FTO} / \mathrm{m}-\mathrm{TiO}_{2} /$ Spriro-OMeTAD/Au & 9.7 & 2012 & [45] \\
\hline $\mathrm{FAPbI}_{3}$ & $\mathrm{FTO} / \mathrm{bl}-\mathrm{TiO}_{2} / \mathrm{mp}-\mathrm{TiO}_{2} / \mathrm{PTAA} / \mathrm{Au}$ & 20.2 & 2015 & {$[46]$} \\
\hline $\mathrm{MA}_{0.6} \mathrm{FA}_{0.4} \mathrm{PbI}_{3}$ & ITO/PTAA/ICBA/C $60 / \mathrm{BCP} / \mathrm{Cu}$ & 18.3 & 2016 & [47] \\
\hline $\mathrm{Cs}_{0.15} \mathrm{FA}_{0.85} \mathrm{~Pb}\left(\mathrm{I}_{0.83} \mathrm{Br}_{0.17}\right)_{3}$ & $\mathrm{FTO} / \mathrm{bl}-\mathrm{TiO}_{2} / \mathrm{mp}^{-\mathrm{TiO}_{2} / \text { Spriro-OMeTAD/Au }}$ & 20.0 & 2016 & [49] \\
\hline $\mathrm{MAPbI}_{3}$ & ITO/PTAA $/ \mathrm{C}_{60} / \mathrm{BCP} / \mathrm{Cu}$ & 20.7 & 2016 & {$[50]$} \\
\hline $\mathrm{FA}_{0.81} \mathrm{MA}_{0.15} \mathrm{PbI}_{2.51} \mathrm{Br}_{0.45}$ & FTO/bl-TiO $2 / \mathrm{mp}-\mathrm{TiO}_{2} /$ spiro-OMeTAD/Au & 20.8 & 2016 & [51] \\
\hline $\begin{array}{c}\mathrm{Cs}_{0.05}\left(\mathrm{MA}_{0.17} \mathrm{FA}_{0.83}\right)_{0.95} \mathrm{~Pb} \\
\left(\mathrm{I}_{0.83} \mathrm{Br}_{0.17}\right)_{3}\end{array}$ & $\mathrm{FTO} / \mathrm{bl}-\mathrm{TiO}_{2} / \mathrm{mp}-\mathrm{TiO}_{2} / \mathrm{PTAA} / \mathrm{Au}$ & 21.1 & 2016 & [49] \\
\hline $\mathrm{MAPbBr}_{3}$ into $\mathrm{FAPbI}_{3}$ & $\mathrm{FTO} /$ thin-barrier $\mathrm{TiO}_{2} / \mathrm{m}-\mathrm{TiO}_{2} / \mathrm{PTAA} / \mathrm{Au}$ & 22.1 & 2017 & {$[52]$} \\
\hline $\mathrm{FAPbI}_{3}-\mathrm{MAPbBr}_{3}$ & $\mathrm{FTO} / \mathrm{d}-\mathrm{TiO}_{2} / \mathrm{mp}-\mathrm{TiO}_{2} / \mathrm{NBH} / \mathrm{P} 3 \mathrm{HT} / \mathrm{Au}$ & 22.7 & 2019 & [53] \\
\hline $\mathrm{Cs}_{0.17} \mathrm{FA}_{0.83} \mathrm{~Pb}\left(\mathrm{I}_{0.97-\mathrm{x}} \mathrm{Br}_{\mathrm{x}} \mathrm{Cl}_{0.03}\right)_{3}$ & $\mathrm{FTO} / \mathrm{bl}-\mathrm{TiO}_{2} / \mathrm{mp}-\mathrm{TiO}_{2} /$ Spriro-OMeTAD/Au & 20.5 & 2020 & [54] \\
\hline $\begin{array}{lr}* \quad \mathrm{MA}-\mathrm{CH}_{3} \mathrm{NH}_{3} ; & \mathrm{PTT} / \\
\text { bisadduct; } & \text { SpiroOM } \\
\mathrm{NBH} \text {-narrow-bandgap-halide; } \mathrm{P}\end{array}$ & $\begin{array}{l}\text { ly- } \mathrm{HC}\left(\mathrm{NH}_{2}\right)_{2} \mathrm{PbI}_{3} ; \quad \mathrm{BCP} \text {-bathocupr } \\
-2,2^{\prime}, 7,7^{\prime} \text {-tetrakis[N,N-di(4-methoxyphen } \\
\text {-poly(3-hexylthiophene) }\end{array}$ & $\begin{array}{l}\mathrm{e} ; \\
\text { imino]-9, }\end{array}$ & $\begin{array}{l}\text { A-in } \\
\text { pirobi }\end{array}$ & $\begin{array}{l}\text { ene- } \mathrm{C}_{60} \\
\text { luorene; }\end{array}$ \\
\hline
\end{tabular}

Recently, the Oxford photovoltaics has achieved a certified PCE of $27.3 \%$ for $1 \mathrm{~cm}^{2}$ perovskite-silicon tandem solar cell [55]. This result defeats the highest recorded PCE of the single-junction silicon solar cell $(26.7 \%)$. This also indicates the emerging performance and rapid development of the PSCs in comparison to silicon solar cells to achieve a similar efficiency [56]. The prevalent efficiency trend of 
various PV cells is further exhibited in Figure 3. Impressive progress on the PCE is being achieved in case of PSC, which is highly dominating over other PV cells. However, solving the problem of transferring high efficiency from laboratory small-area devices to large-area perovskite modules is the pivotal challenge. The maximum theoretical PCE (Shockley-Queisser limit) of the PSCs, employing $\mathrm{MAPbI}_{3-\mathrm{x}} \mathrm{C}_{\mathrm{lx}}$ is predicted to $31.4 \%$. Therefore, there is still enough space for development [57].

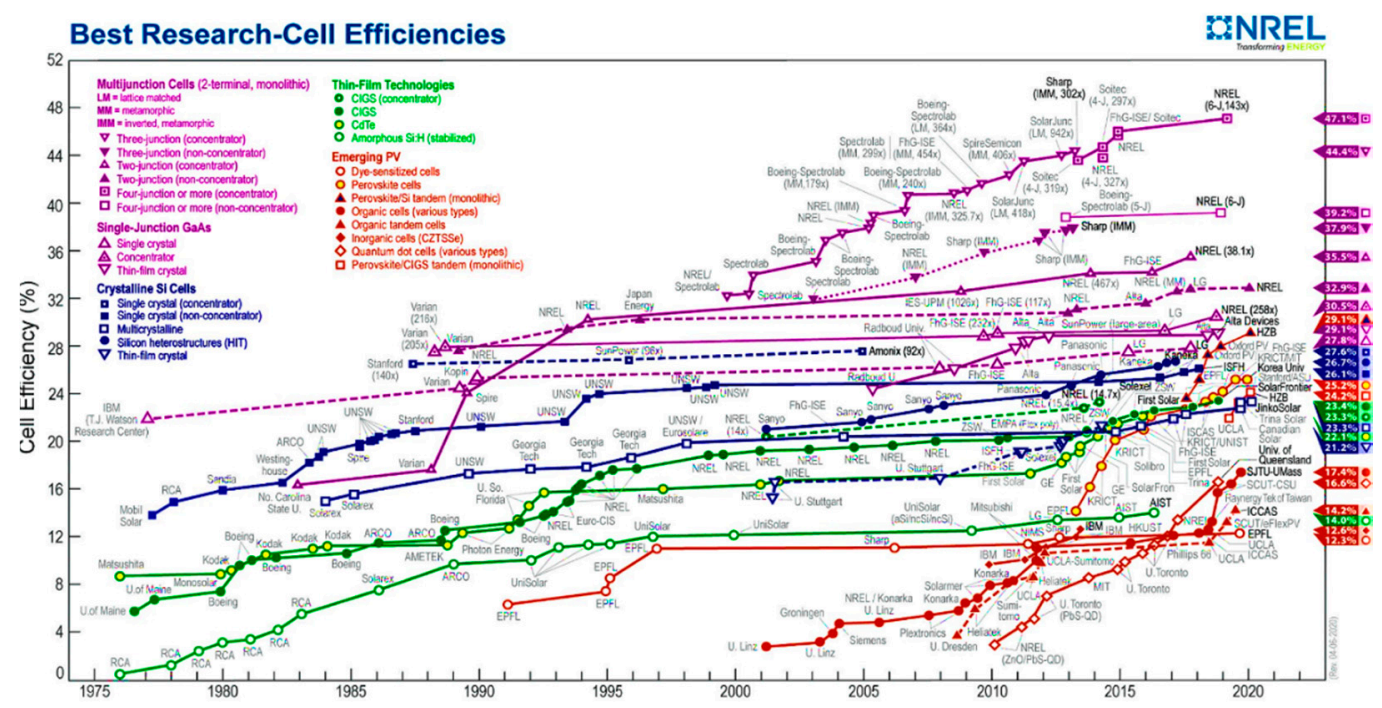

Figure 3. Cell efficiency progress trend of various PV devices (This plot is courtesy of the National Renewable Energy Laboratory, Golden, CO) [44].

Recently, Nishigaki et al. (2020) show simulations study based on light absorption characteristics of chalcogenide alloy-based perovskites such as $\mathrm{Ba}(\mathrm{Zr}, \mathrm{Ti}) \mathrm{S}_{3}$, indicating a maximum potential of $38.7 \%$ PCE in a perovskite/crystalline Si tandem structure [58]. Despite intrinsically excellent optoelectronic properties of the perovskite absorber, a gap between the theoretical efficiency and the experimental one opens up an ample scope of further investigation and detailed scrutiny to unveil the hidden information of achieving high efficiency and stable PSC. All other kinds of non-Si solar cells suffer significant barriers in terms of their materialization, fabrication and cost and thus became almost saturated to develop next-generation PV devices. In this scenario, the rapid improvement of PSCs thus is expected to be a prominent choice than the traditional silicon solar cells [59].

Efficiency and operation stability both are the crucial factors to determine the practical applications of these devices. Therefore, to execute the best performance of a PSC, there are several fundamental concerns needs to be addressed as mentioned:

- Excellent improvement of photo physics-chemistry and dynamics of exciton/charge-carrier;

- Well-established interfacial energy alignment, interface electronic structure and charge-transfer (carrier-collection) processes;

- Structural and composition characterization;

- Improved stability by developing material and compositional engineering;

- High-efficiency solar cell fabrication with device performance and stability testing;

- Scale-up, printing, slot-die coating and roll-to-roll manufacturing;

- Understanding of solar parameter behaviour.

\section{Device Challenges: Stability and Toxicity Affairs of PSCs}

To develop highly efficient and environmentally stable, benign perovskite devices is critical and challenging. Particularly for BIPV application, semi-transparent or transparent PSCs are required as they not only generate power for the building but also allows daylight and improve the indoor environment. However, for opaque façade application, the requirement for the transparency can be 
eliminated. Long-term instability, use of toxic lead $(\mathrm{Pb})$ and semitransparency, while having higher power generating capability are the significant challenges with PSC.

As mentioned, stability stands out as the main challenge of a PSC device. The perovskite layer degrades rapidly in the presence of high temperature, ultraviolet (UV) light and moisture (Figure 4). Moreover, $\mathrm{Pb}$-based perovskite $\left(\mathrm{MAPbI}_{3}\right)$ causes severe toxicological implications on the environment with a dramatic impact on the environment and human health. Rapid degradation is the most common phenomenon for PSC while they are exposed to moisture and UV radiation [60,61]. This is quite a realistic point to be considered for outdoor application. Consequently, effective strategies are required to overcome the stability issue and employed for long-term running [62]. As a result, besides the implementation of high-efficiency devices, it is also essential to consider on environment and safety issues for an optimum PSC device.

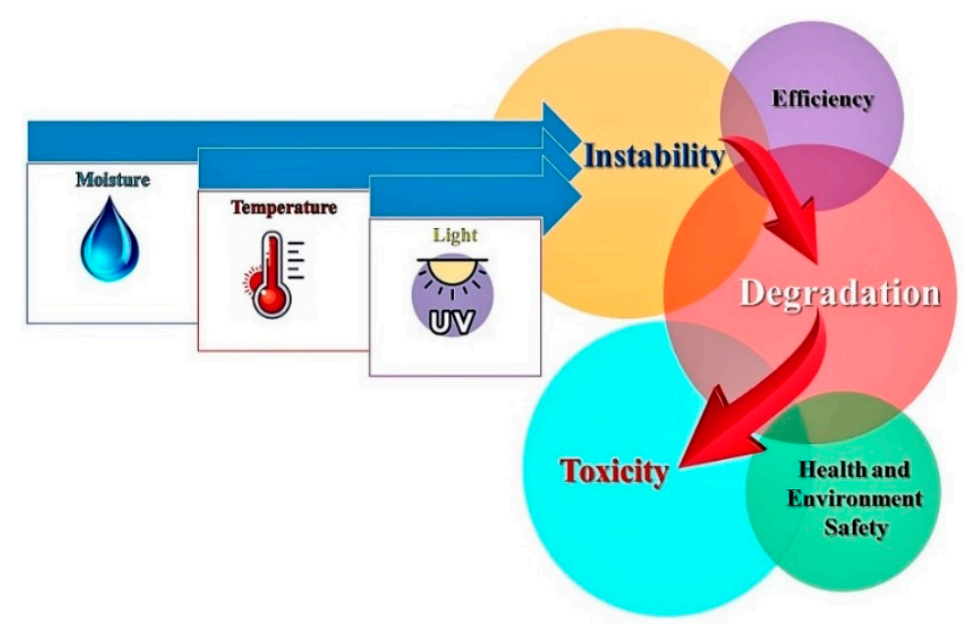

Figure 4. Major challenges of PSCs according to instability and toxicity.

\subsection{Stability Issue}

$\mathrm{MAPbI}_{3}$-based perovskite is the most efficient candidate for high PCE generation, but they suffer from material degradation in the presence of high temperature, intense UV light and the high percentage of moisture content $[63,64]$. The hygroscopic character of amine salt present in $\mathrm{MA}^{+}$and highly hydrophilic nature of perovskite lead the hydrate products formation, which eventually broadens the degradation time [65-67]. In the presence of UV-light photogenerated electron ease the formation of superoxide $[68,69]$, which are moderately reactive with perovskite. The degradation leads to the formation of $\mathrm{PbI}_{2}$ and $\mathrm{HI}$, which further produce $\mathrm{I}_{2}$ in the presence of oxygen, as shown in the equation (i-iii). The UV-degradation can also happen for encapsulated devices [70,71]. Organic-inorganic perovskites have various thermal stabilities depending on the time of exposure. Grain boundaries play a crucial role in temperature-dependent stability $[72,73]$. Depends on the organic part of the material, degradation can occur at $60^{\circ} \mathrm{C}$ or can start at $100{ }^{\circ} \mathrm{C}$ [74-76]. Not only the perovskite materials; there are other layers like HTL, ETL and metal-based electrode materials, which also have their fundamental issues [77-80]. The metal electrode has the tendency to be corroded by the degradation of halide perovskite and tends to produce metal halide due to temperature stress. Stability issues can also occur from a structural point of view. The crystal structure of the perovskite and tolerance factor plays a pivotal role as they dictate the performance of the perovskite [81].

$$
\begin{gathered}
\mathrm{CH}_{3} \mathrm{NH}_{3} \mathrm{PbI}_{3} \text { (s) } \rightarrow \mathrm{PbI}_{2} \text { (s) }+\mathrm{CH}_{3} \mathrm{NH}_{3} \mathrm{I} \text { (aq.) } \\
\mathrm{CH}_{3} \mathrm{NH}_{3} \mathrm{I} \text { (aq.) } \rightarrow \mathrm{CH}_{3} \mathrm{NH}_{2} \text { (aq.) }+\mathrm{HI} \text { (aq.) } \\
\mathrm{HI} \text { (aq.) }+\mathrm{O}_{2} \text { (g) } \rightarrow 2 \mathrm{I}_{2} \text { (s) }+2 \mathrm{H}_{2} \mathrm{O} \text { (L) }
\end{gathered}
$$


To solve the moisture instability, two-dimensional (2D) perovskites and mixed dimensional perovskites are the most promising ones [82,83]. Incorporation of 2D perovskite in the grain boundary of three-dimensional (3D) perovskite has also proven to be effective in passivating the defect states of grain boundary $[84,85]$. Protection of PSCs from UV-light can also be achieved by using mixed dimensional (2D-3D) perovskite materials. At the same time, incorporation of inorganic charge transport materials like $\mathrm{CuSCN}, \mathrm{NiO}, \mathrm{WO}_{3}$ also provides some promising light stability in ambient conditions [86-88]. In spite of that, encapsulation is another way out to protect the devices from external factors [85]. Encapsulating materials play a huge role in commercializing PSCs, although UV instability is a matter of concern even with encapsulated devices. Thermal stability can be managed using the perovskite materials having high tolerance factor and quasi-2D structures. Using inorganic charge transport layers via sol-gel and pyrolysis methods effectively reduce the chances of degradation [89-91]. Presently, a considerable amount of study is going on by replacing the metal electrodes with carbon-based materials [92], which are non-degradable by corrosion. Hence, incorporation of carbon nanostructures as the charge transport layer take new initiatives for stable and economically viable PCE [93]. Few examples are given in Table 3, showing the developments of PSCs to overcome different instability factors. Perovskite-silicon tandem cells are coming in the market to make it more feasible for energy application [94].

Table 3. Types of PSCs along with their efficiency and stability.

\begin{tabular}{|c|c|c|c|}
\hline Device Structure & PCE (\%) & Stability Status & Reference \\
\hline ITO/ZnO-JTCA/MAPbI $3 /$ spiro-MeOTAD/Au & 18.8 & $70 \%$ left after $840 \mathrm{~h}$ in air & [95] \\
\hline ITO/PEDOT:PSS/MAPbI ${ }_{3-\mathrm{x}} \mathrm{Cl}_{\mathrm{x}} / \mathrm{PCBM} / \mathrm{ZnO} / \mathrm{Al}$ & 16.8 & Excellent stability & [96] \\
\hline 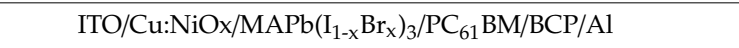 & 15.4 & 244 h stability & [97] \\
\hline $\mathrm{ITO} / \mathrm{NiO} / \mathrm{MAPbI}_{3} / \mathrm{ZnO} / \mathrm{Al}$ & 16.1 & $>60$ d stability & [98] \\
\hline $\mathrm{FTO} / \mathrm{SnO}_{2} / \mathrm{FA}_{1-\mathrm{x}}(\mathrm{MACs})_{\mathrm{x}} \mathrm{PbI}_{3} /$ spiro-MeOTAD/Au & 20.7 & $83 \%$ left after $60 \mathrm{~h}$ & [96] \\
\hline $\mathrm{FTO} / \mathrm{TiO}_{2} / \mathrm{MAPbI}_{3-\mathrm{x}} \mathrm{Clx} /$ sputtered $\mathrm{NiO}_{\mathrm{x}} / \mathrm{Ni}$ & 7.3 & $>2$ months stability & [99] \\
\hline $\mathrm{FTO} / \mathrm{NiO}_{x} / \mathrm{FA}_{1-x} \mathrm{MA}_{x} \mathrm{PbI}_{3} / \mathrm{PCBM} / \mathrm{TiO}_{x} / \mathrm{Ag}$ & 20.7 & $90 \%$ left after $500 \mathrm{~h}$ under $85^{\circ} \mathrm{C}$ & [100] \\
\hline $\begin{array}{l}\mathrm{ITO} / \mathrm{PTAA} /\left(\mathrm{FA}_{0.83} \mathrm{MA}_{0.17}\right)_{0.95} \mathrm{Cs}_{0.05} \\
\mathrm{~Pb}\left(\mathrm{I}_{0.6} \mathrm{Br}_{0.4}\right)_{3} / \mathrm{ICBA} / \mathrm{C}_{60} / \mathrm{BCP} / \mathrm{Cu}\end{array}$ & 18.3 & $90 \%$ left after $720 \mathrm{~h}$ in $\mathrm{N}$ & [101] \\
\hline 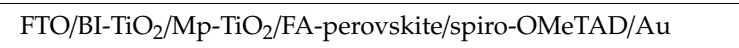 & 20.0 & $800 \mathrm{~h}$ & [102] \\
\hline FTO/bl- $\mathrm{TiO}_{2} / \mathrm{mp}-\mathrm{TiO}_{2} /{\mathrm{RuCsFAMAPbI} 1{ }^{-} \mathrm{Br}}_{\mathrm{x}} /$ spiro-MeOTAD/Au & 21.8 & $95 \%$ left after $500 \mathrm{~h}$ under $85^{\circ} \mathrm{C}$ & [103] \\
\hline $\mathrm{FTO} / \mathrm{bl}-\mathrm{TiO}_{2} / \mathrm{mp}-\mathrm{TiO}_{2} / \mathrm{CsFAMAPbI}_{3-\mathrm{x}} \mathrm{Br}_{\mathrm{x}} / \mathrm{CuSCN} / \mathrm{RGO} / \mathrm{Au}$ & 20.4 & $95 \%$ left after $1000 \mathrm{~h}$ under $60^{\circ} \mathrm{C}$ & [87] \\
\hline $\mathrm{FTO} / \mathrm{c}-\mathrm{TiO}_{2} / \mathrm{m}-\mathrm{TiO}_{2} / \mathrm{m}-\mathrm{ZrO}_{2} / \mathrm{Co}_{3} \mathrm{O}_{4} / \mathrm{carbon} / \mathrm{MAPbI}_{3}$ & 11.7 & $\begin{array}{l}\sim 2500 \mathrm{~h} \text { in ambient condition in } \\
\text { presence of light }\end{array}$ & [104] \\
\hline $\mathrm{FTO} / \mathrm{m}-\mathrm{TiO}_{2} / \mathrm{m}-\mathrm{ZrO}_{2} / \mathrm{NiO} /$ carbon/MAPbI ${ }_{3}$ & 13.7 & $\begin{array}{l}\text { PCE decreased to } 80 \% \text { of initial } \\
\text { after } \sim 150 \mathrm{~h} \text { in presence of light }\end{array}$ & [105] \\
\hline $\mathrm{FTO} / \mathrm{c}-\mathrm{TiO}_{2} / \mathrm{m}-\mathrm{TiO}_{2} / \mathrm{CH}_{3} \mathrm{NH}_{3} \mathrm{PbI}_{3} / \mathrm{C}-\mathrm{CuS}$ & 10.2 & $\begin{array}{l}\text { Over } 600 \mathrm{~h} \text { in ambient condition } \\
\text { with } 30 \%-50 \% \text { humidity in dark }\end{array}$ & [106] \\
\hline $\mathrm{FTO} / \mathrm{c}-\mathrm{TiO}_{2} / \mathrm{m}-\mathrm{TiO}_{2} / \mathrm{m}-\mathrm{ZrO}_{2} /$ carbon$/ \mathrm{MAPbI}_{3}$ & 6.5 & $\begin{array}{l}\sim 850 \mathrm{~h} \text { in dry air condition at } \\
\text { room temperature in dark }\end{array}$ & [107] \\
\hline $\mathrm{FTO} / \mathrm{c}-\mathrm{TiO}_{2} / \mathrm{m}-\mathrm{TiO}_{2} / \mathrm{m}-\mathrm{Al}_{2} \mathrm{O}_{3} /$ carbon/MAPbI 3 & 12.3 & $\begin{array}{l}\text { PCE decreased to } 1 \% \text { of initial } \\
\text { after } \sim 480 \mathrm{~h} \text { under light at room } \\
\text { temperature }\end{array}$ & [107] \\
\hline $\mathrm{FTO} / \mathrm{c}-\mathrm{TiO}_{2} / \mathrm{m}-\mathrm{TiO}_{2} / \mathrm{m}-\mathrm{Al}_{2} \mathrm{O}_{3} / \mathrm{SWCNT}-\mathrm{NiO} / \mathrm{MAPbI}_{3}$ & 12.7 & $\sim 300 \mathrm{~h}$ in ambient condition & [108] \\
\hline $\mathrm{FTO} / \mathrm{c}-\mathrm{TiO}_{2} / \mathrm{m}-\mathrm{TiO}_{2} / \mathrm{m}-\mathrm{Al}_{2} \mathrm{O}_{3} /$ carbon- $\mathrm{WO}_{3} / \mathrm{MAPbI}_{3}$ & 10.3 & $\begin{array}{l}85 \% \text { of initial PCE retains after } \\
\sim 500 \mathrm{~h} \text { in the ambient condition in } \\
\text { the presence of light }\end{array}$ & [109] \\
\hline
\end{tabular}

Degradation of perovskite is the main reason for instability as mentioned above. Poor thermal stability over a long period and also the humidity related adverse effects contribute towards the degradation of the $\mathrm{Pb}$-based perovskite $[63,64,92]$. Resolving the stability issues of perovskite material is the censorious strategy to upgrade the long-term performances. 
The growth of PSC confirmed that trying to leap directly into the marketplace BIPV installations would require substantial upfront capital investment. However, the standard test condition, STC (using the air-mass 1.5 spectrum, an intensity of $100 \mathrm{~mW} \cdot \mathrm{cm}^{-2}$ also known as 1 sun of illumination and a cell temperature of $25^{\circ} \mathrm{C}$ ) is vastly different from real-world conditions, where temperature and the solar light intensity level and its spectrum always change with time [110,111]. Tress et al. (2019) recently varied both the light intensity and temperature of a PSC to monitor the PCE performing outdoor experiments at Lausanne, Switzerland. They have realized that temperature and solar light intensity closely depend on the associate weather condition, which determines the PV parameters associated with the PSCs [111]. As an example, based on weather station data from Bangor University in the UK from 2018, there were just 51.4 h over the whole year where the solar irradiance was equal to or greater than 1 sun and the mean irradiance during daylight hours was only 0.226 sun [110].

\subsection{Toxicity Issue}

As mentioned in Section 2, the most efficient PSCs are fabricated using Pb-based halide perovskites $\left(\mathrm{MAPbI}_{3}\right)$. However, they suffer from the toxicity issues during device fabrication, deployment and disposal [112,113], which also retards the pace of commercialization. $\mathrm{Pb}$ is a carcinogenic element and has no safe threshold limit of exposure. Degradation of $\mathrm{MAPbI}_{3}$ due to $\mathrm{pH}$ from rainwater on $\mathrm{MAPbI}_{3}$ films were characterized and found that it degrades completely in water [114]. Moreover, a recent report by $\mathrm{Li}$ et al. (2020) highlights $\mathrm{Pb}$ - leakage into the ground, which can further provide serious impact on plants and human's food cycle [115]. In addition, Su et al. (2020) have examined the impact of Pb-leakage on the environment. They have observed that the total organic carbon and chemical oxygen demand analysis signify discarded PSCs could increase the oxygen consumption and may release $\mathrm{CO}_{2}$ into the environment [116].

The toxic effect of $\mathrm{Pb}$ and polymers pushed researchers to think about greener alternatives $[60,112,117,118]$. Tin, germanium, bismuth can replace the toxic $\mathrm{Pb}[119,120]$. Moreover, some new series of materials as chalcogenide perovskites, double perovskites, etc. are also worth investigating [121,122]. Various alternative Pb-free perovskite materials can be employed for light absorbers in PSCs. Table 4 indicates about the performance of some notable $\mathrm{Pb}$-free perovskite absorber development. However, the efficiency is not as much like $\mathrm{Pb}$-based perovskites due to high minority and low mobility of carrier-effective masses. Still, they are in the investigation because of their better stability over Pb-based PSCs at ambient condition.

Table 4. Significant performance of various lead-free perovskite-based materials in PSCs.

\begin{tabular}{|c|c|c|c|}
\hline Pb-Free Absorber & Features & PCE (\%) & Reference \\
\hline $\mathrm{CsSnI}_{3}$ & $\begin{array}{c}\mathrm{CsSnX}_{3}(\mathrm{X}=\mathrm{Cl}, \mathrm{Br} \text { and } \mathrm{I}) \text { quantum rods with tunable } \\
\text { emission wavelength ranging from } 625 \text { to } 709 \mathrm{~nm} \text { has } \\
\text { been prepared via solvothermal synthesis using } \\
\text { different halide salt conditions }\end{array}$ & 13.0 & [123] \\
\hline $\mathrm{CsSnI}_{3}$ & $\begin{array}{l}\text { Addition of } \mathrm{SnF}_{2} \text { reduces the background charge } \\
\text { carrier density by lowering the defect concentrations }\end{array}$ & 2.0 & [124] \\
\hline $\mathrm{Cs}_{2} \mathrm{TiBr}_{6}$ & $\begin{array}{l}\text { First-ever solar cells using } \mathrm{Cs}_{2} \mathrm{TiBr}_{6} \text { thin films show a } \\
\text { stable efficiency of up to } 3.3\end{array}$ & 3.3 & [125] \\
\hline Sn-based & $\begin{array}{l}\text { Tin perovskite solar cells by using high energy level } \\
\text { Indene- } C_{60} \text { bisadduct }\end{array}$ & 12.4 & [126] \\
\hline $\mathrm{MASnI}_{3}$ & $\begin{array}{l}\text { Redshifted and absorption up to } 950 \mathrm{~nm} \text {, compared to } \\
\qquad \mathrm{MAPbI}_{3} \text { counterpart }(1.55 \mathrm{eV}) .\end{array}$ & 5.7 & [127] \\
\hline $\mathrm{FASnI}_{3}$ & $\begin{array}{l}\text { Lewis acid-base adduct formed crystallization with } \\
\text { trimethylamine }\end{array}$ & 7.1 & [128] \\
\hline
\end{tabular}


Table 4. Cont.

\begin{tabular}{|c|c|c|c|}
\hline Pb-Free Absorber & Features & PCE (\%) & Reference \\
\hline $\mathrm{MAGeI}_{2.7} \mathrm{Br}_{0.3}$ & $\begin{array}{l}\text { Flash-photolysis time-resolved microwave } \\
\text { conductivity and photoelectron yield spectroscopy } \\
\text { techniques }\end{array}$ & 0.6 & [129] \\
\hline $\mathrm{Cs}_{2} \mathrm{AgBiBr}_{6}$ & $\begin{array}{c}\text { Fabricated } \mathrm{Cs}_{2} \mathrm{AgBiBr}_{6} \text { films and incorporation to } \\
\text { working devices }\end{array}$ & 2.5 & [130] \\
\hline $\mathrm{MA}_{3} \mathrm{Bi}_{2} \mathrm{I}_{9}$ & $\begin{array}{l}\text { Pinhole-free, large-grained films fabrication using two } \\
\text { steps approach. The absorption coefficient, trap } \\
\text { density of states characterization and charge diffusion } \\
\text { length comparison to lead perovskite. }\end{array}$ & 1.6 & [131] \\
\hline $\mathrm{MASbSI}_{2}$ & $\begin{array}{l}\text { methylammonium antimony sulfur diiodide was } \\
\text { fabricated the first time for solar cell }\end{array}$ & 3.1 & [132] \\
\hline $\mathrm{MA}_{3} \mathrm{Sb}_{2} \mathrm{Cl}_{X} \mathrm{I}_{9-\mathrm{X}}$ & $\begin{array}{l}\text { A joint experimental and theoretical study. } \\
\text { Inclusion of methylammonium chloride into the } \\
\text { Precursor solution; low-cost fabrication }\end{array}$ & 2.2 & [132] \\
\hline $\mathrm{MA}_{2} \mathrm{KBiCl}_{6}$ & Indirect bandgap, density functional calculations & 3.0 & [133] \\
\hline $\begin{array}{l}\mathrm{Ba}(\mathrm{Zr}, \mathrm{Ti}) \mathrm{S}_{3} \\
\quad \text { and } \\
\mathrm{BaZr}(\mathrm{S}, \mathrm{Se})_{3}\end{array}$ & $\begin{array}{l}\text { Perovskite/crystalline Si tandem architecture, } \\
\text { indicating the highest band-edge } \alpha \text { among all known } \\
\text { solar cell materials; Theoretical study }\end{array}$ & 38.0 & [58] \\
\hline
\end{tabular}

\section{Photovoltaic Consequences of PSCs}

\subsection{Transparency and Efficiency Tradeoff of PSCs}

Transparency is a crucial factor to determine the PCE of PSCs. Therefore, it is imperative to study the semi-transparent PSCs towards its useful energy harvesting through the windows and roofs of buildings. The transmitted sunlight through the transparent or semi-transparent window of a building significantly influences on the visual comfort of building occupant. Besides PCE, there are some other crucial parameters such as average visible transmittance (AVT), transparency colour perception [134-136], corresponding colour temperature (CCT) $[137,138]$ and colour rendering index (CRI) [139] should be investigated for optimizing the semi-transparent PSCs. Usually, AVT range between $20 \%-30 \%$ is required for window applications. Bandgap tuning of the perovskite absorber resolves the tradeoff between transparency and efficiency and thus becoming as a smart choice as a window. Transparency is associated with the thickness of the cell. Sometimes, highly transparent cells suffer low efficiency due to less absorption of sunlight. In contrast, less transparent cells are sometimes insufficient to generate the required power [140,141]. Jung et al. (2015) have described transparency enhancement by reducing the Perovskite absorber coverage. The PCE significantly boosts up by $128 \%$, while the thickness increased from 40 to $280 \mathrm{~nm}$, followed by the AVT decreased from 35\% to 10\% [142].

The modern architects prefer to build exteriors designed with artwork on the glass while building engineers consider low-cost energy-efficient construction [143,144]. Transparent or semi-transparent solar cell devices can replace the transparent glass for building. However, the fully transparent solar cell possesses low solar light absorption capability. Hence it is a critical task to fabricate a fully transparent solar cell, which will also generate high power [145]. Thus, optimization between the efficiency and transparency at acceptable levels by varying the thickness of the different layers are required [146-148]. The light transmission with opaque crystalline Si PV is achieved by spacing the cells in the module $[21,22,149]$ whereas PSCs are semi-transparent elements. An effort has been executed to find a suitable medium between high electrical efficiency and a high AVT, as shown in Figure 5. The thickness and structure of the mesoporous layer create an impact on PSC performance [150]. The optical transparency of the other interlayers and the semi-transparent electrode of PSC influence to archive high PCE [151]. Therefore, to achieve a highly transparent PSC device, the perovskite layer 
should be thin enough, which inevitably leads to obtain brownish cells [152]. In addition, reducing the thickness of the perovskite layer cannot wholly solve the tradeoff between transparency and efficiency as improvement of the transparency decrease the efficiency [153]. Mesoscopic cells that use $\mathrm{TiO}_{2}$ photoanodes are partially circumvented. By providing a large $\mathrm{MAPbI} / \mathrm{TiO}_{2}$ interfacial surface area, electrons are therefore extracted from the perovskite throughout the entire thickness of the layer [71]. Thin mesoporous $\mathrm{TiO}_{2}$ layer has the potential to fill pore, which results in an improved PCE [154].

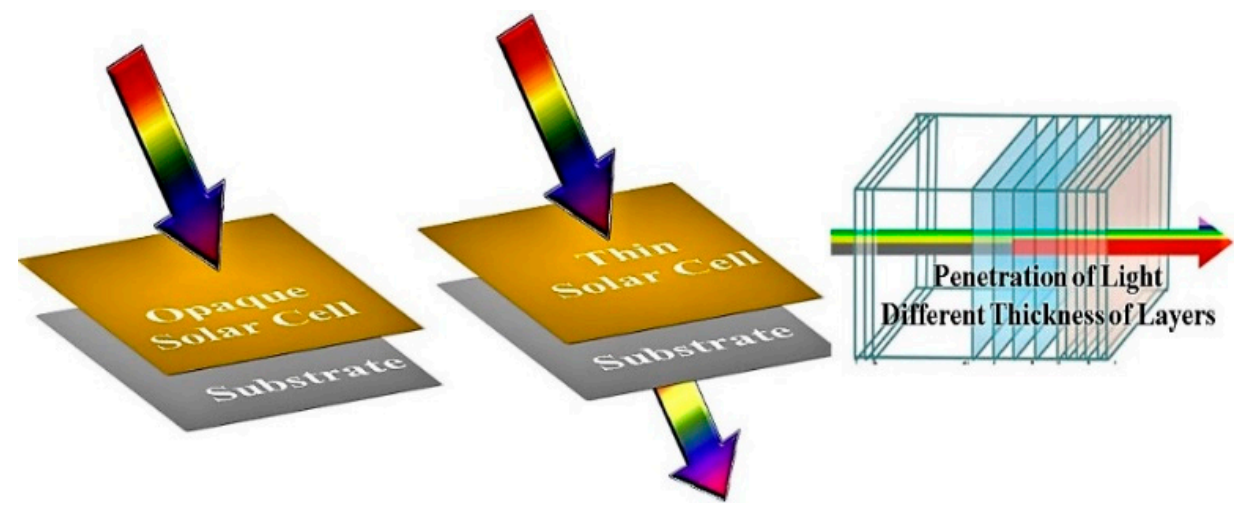

Figure 5. Schematic representation of the transparency of light, indicating the thickness of the different layer of a PSC.

Various reports claimed that a thin film of $\mathrm{MAPbI}_{3}$ could be developed, consisting of a thickness of 100-350 nm [155-157]. This resulted in the substantial differences in carrier diffusion lengths of the compositions, a much deeper understanding of the role of film thickness and morphology on the efficiency of $\mathrm{MAPbI}_{3}$-based planar heterojunctions is required. The influence of the $\mathrm{TiO}_{2}$ layer during the growth of the perovskite "pores", determined mainly by the thickness of the film by using their non-stoichiometric mixture of MAI and $\mathrm{PbCl}_{2}$ precursors was also studied. Employing perovskite de-wetting technique, neutral colour perovskite was synthesized, which has an array of perovskite microstructured island. Each island could absorb visible light while the transparent region was colour neutral. However, this structure offers high transmission, but the gap between perovskite island create high shunt resistance $[158,159]$. This shunt resistance lowers the power generation, which can be further improved by -post-treatment of perovskite using alkyl-siloxane molecular layers [160]. The morphologic control of the perovskite layer is much determined by their precursors, deposition method and preparation temperature [161]. Without hole transport material, PSC having photoanode of $800 \mathrm{~nm}$ shows $12.22 \%$ cell efficiency [162]. It is observed that thinner n-type layers would improve the conductivity and accordingly lead to better device performance. Consequently, an appropriate thickness of n-type layers is also paramount to achieve superior device performance [163,164].

Yuan et al. (2018) investigated systematically by varying the I: $\mathrm{Br}$ ratio for $\mathrm{MAPb}(\mathrm{Br}, \mathrm{I})_{3}$-based perovskites and thickness of the corresponding film, which led to an increase in the AVT as well as PCE [141]. They have realized that $>20 \%$ AVT and $\sim 10 \%$ PCE, even when the device thickness of wide-bandgap perovskite was $>200 \mathrm{~nm}$. A sandwich-type $\mathrm{MAPbI}_{3}$ to obtain semi-transparent PSCs with high efficiency by modification of morphology and structure, which can increase transparency to some extent, as reported by Heo et al. (2016) [163]. Wei et al. (2019) reported semi-transparent PSC-based on $\mathrm{MoO}_{\mathrm{x}} / \mathrm{ITO} / \mathrm{Ag} / \mathrm{ITO}\left(\mathrm{MoO}_{\mathrm{x}} / \mathrm{IAI}\right)$ with $\mathrm{MAPbI}_{3}$, which exhibited a PCE of $12.85 \%$ with an AVT of $~ 80 \%$. Ag nanowire is deposited on the spiro-OMeTAD or perovskite to attain a semi-transparent PSC, which achieved a peak transmission of $77 \%$ approximately $800 \mathrm{~nm}$ and an efficiency of $12.7 \%$ as reported by Bailie et al. (2015) [165]. The PCE of $14.2 \%$ along with $72 \%$ AVT in the near-infrared region has been reported Fu et al. (2015) for an FTO/ZnO/PCMB/MAPbI $3 / \mathrm{Au}$ based device architecture [166].

On the other hand, the strategy for achieving high transparency relies on uniform microstructure within the perovskite film, such as inserting a passivating material to confine the growth of perovskite grains. Mesh assisted grid deposition technique for mixed cation mixed halide perovskite on 
mesoporous $\mathrm{TiO}_{2}$ was employed to fabricate PSC, which resulted in an average PCE $~ 10 \%$ with an AVT of $28 \%$. In this case, islands of perovskite well-connected across the walls of the mesh are formed, which are capable of efficient light conversion and provide intermittent surface coverage for average transparency [167]. Table 5 highlights the performance of the investigated semi-transparent PSCs. Notably, both electrically conductive and optically transparent perovskite materials are still challenging to develop.

Table 5. The efficiency of various semi-transparent PSCs at their different transmission wavelength.

\begin{tabular}{|c|c|c|c|c|}
\hline Device Structure & PCE (\%) & Transmittance (\%) & Wavelength (nm) & Reference \\
\hline ITO/PTAA/Cs ${ }_{0.05} \mathrm{FA}_{0.8} \mathrm{MA}_{0.15} \mathrm{PbI}_{2.55} \mathrm{Br}_{0.45} / \mathrm{C}_{60} / \mathrm{SnO}_{2} / \mathrm{ZTO} / \mathrm{IZO}$ & 18.2 & 75 & $760-1200$ & [168] \\
\hline ITO/PEDOT:PSS/MAPbI $\mathrm{Cl}_{3-x}-\mathrm{PVP} / \mathrm{CYTOP} / \mathrm{PC}_{61} \mathrm{BM} / \mathrm{PEIE} / \mathrm{Au}$ & 5.4 & 34 & $400-800$ & [169] \\
\hline $\begin{array}{c}\mathrm{FTO} / \mathrm{c}-\mathrm{TiO}_{2} / \mathrm{MAPbI}_{3} / \mathrm{Spiro} \mathrm{OMeTAD} / \mathrm{MoO}_{3} / \\
\mathrm{Au} / \mathrm{MoO}_{3}\end{array}$ & $5.3-13.6$ & 7-31 & $370-740$ & [170] \\
\hline $\mathrm{FTO} / \mathrm{c}-\mathrm{TiO}_{2} / \mathrm{MAPbI}_{\mathrm{X}} \mathrm{Cl}_{3-\mathrm{X}} /$ Spiro-OMeTAD/Ni & 6.1 & 38 & $300-850$ & [160] \\
\hline $\mathrm{FTO} / \mathrm{c}-\mathrm{TiO}_{2} / \mathrm{AAO}+\mathrm{MAPbI}_{3-\chi} \mathrm{Cl}_{X} /$ Spiro-OMeTAD/MoOX/ITO & $8.5-13.3$ & $26.3-45.4$ & $400-800$ & [171] \\
\hline $\mathrm{In}_{2} \mathrm{O}_{3}: \mathrm{H} / \mathrm{PTAA} / \mathrm{MAPbI}_{3} / \mathrm{PC}_{61} \mathrm{BM} / \mathrm{ZnO} \mathrm{ZnO}: \mathrm{Al} / \mathrm{Ni} / \mathrm{Al}$ & 16.1 & 80.4 & $800-1200$ & [146] \\
\hline $\mathrm{ITO} / \mathrm{CuSCN} / \mathrm{MAPbI}_{3} / \mathrm{PCBM} / \mathrm{Bis}^{-\mathrm{C}_{60} / \mathrm{Ag}}$ & $7.5-10.7$ & $13-37.5$ & $300-850$ & [142] \\
\hline $\mathrm{FTO} / \mathrm{c}-\mathrm{TiO}_{2} / \mathrm{MAPbI}_{3} / \mathrm{PTAA} / \mathrm{PEDOT}: \mathrm{PSS} / \mathrm{ITO} /$ glass & $12.6-15.8$ & $6.3-17.3$ & $300-800$ & [172] \\
\hline ITO/PEDOT:PSS/MAPbI/ $/ \mathrm{PCBM} / \mathrm{AZO} \mathrm{SnO}_{x} / \mathrm{Ag} / \mathrm{SnO} \mathrm{x}$ & 11.8 & 29 & $400-900$ & [173] \\
\hline 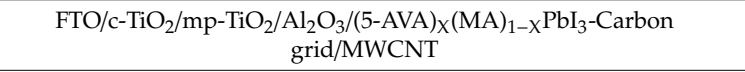 & 8.2 & 24 & $300-800$ & [174] \\
\hline ITO/ZnO/CsPbBr $/$ /Spiro-OMeTAD/PH1000 & 5.9 & 59.8 & $300-800$ & [175] \\
\hline $\begin{array}{l}\mathrm{FTO} / \mathrm{TiO}_{2} / \mathrm{MAIPbI}_{3}-\mathrm{CH}_{3} \mathrm{NH}_{2}-\mathrm{MAPbI}_{3} / \mathrm{SWCNT} / \mathrm{PEDOT}: \mathrm{PSS} / \mathrm{Ni} \\
\text { microgrid }\end{array}$ & 11.3 & 68 & $380-740$ & [176] \\
\hline $\mathrm{ITO} / \mathrm{c}-\mathrm{TiO}_{2} / \mathrm{mp}-\mathrm{TiO}_{2} / \mathrm{Rb}-\mathrm{FA}_{0.75} \mathrm{MA}_{0.15} \mathrm{Cs}_{0.1} \mathrm{PbI}_{2} \mathrm{Br} / \mathrm{PTAA} / \mathrm{MoO}_{X} / \mathrm{ITO}$ & 16 & 84 & $720-1100$ & [177] \\
\hline $\begin{array}{c}\mathrm{ITO} / \mathrm{NiO}_{\mathrm{X}} / \mathrm{FA}_{0.83} \mathrm{Cs}_{0.17} \mathrm{PbBr}_{0.5} \mathrm{I}_{0.25} / \mathrm{LiF} / \mathrm{PC}_{60} \mathrm{BM} / \mathrm{SnO}_{2} / \mathrm{ZTO}: \mathrm{ITO} / \mathrm{LiF} / \mathrm{Ag} \\
\text { grid }\end{array}$ & 14.5 & 74 & $765-1200$ & [178] \\
\hline ITO/PEDOT:PSS/MAPbI $/ \mathrm{PC}_{61} \mathrm{BM} / \mathrm{Au} / \mathrm{LiF}$ & $3.4-7.7$ & $10-35.4$ & $400-800$ & [179] \\
\hline $\mathrm{ITO} / \mathrm{NiO}_{\mathrm{X}} / \mathrm{MA}_{3} \mathrm{PbI}_{3} / \mathrm{PCBM} / \mathrm{BCP} / \mathrm{Ag} / \mathrm{SiO}_{2} / \mathrm{ZnS} / \mathrm{Ag} / \mathrm{ZnS}$ & $\begin{array}{l}10.5,10.7 \\
11.2\end{array}$ & $28.8,12.4,3.4$ & $\begin{array}{l}\text { Red, Green, } \\
\text { Blue }\end{array}$ & [180] \\
\hline $\mathrm{ITO} / \mathrm{ZnO} / \mathrm{PCBM} / \mathrm{MAPbI}_{3} / \mathrm{NiO}_{\mathrm{X}} / \mathrm{ITO} /$ dielectric mirror & 10.12 & $28.1,22.4,17.4$ & Red, Green, Blue & [181] \\
\hline $\mathrm{FTO} / \mathrm{c}-\mathrm{TiO}_{2} / \mathrm{m}-\mathrm{TiO}_{2} / \mathrm{MAPbCl}_{\mathrm{X}} \mathrm{I}_{3-\mathrm{x}} / \mathrm{Spiro-OMeTAD/PEDOT:PSS}$ & $\begin{array}{l}\text { 11.6, } 13.8 \\
11.6\end{array}$ & $11.6,10.5,9.1$ & $400-750$ & [182] \\
\hline $\begin{array}{c}\mathrm{ITO} / \mathrm{c}-\mathrm{TiO}_{2} / \mathrm{MAPbI}_{3} / \text { Spiro-OMeTAD } / \mathrm{MoO}_{3} / \\
\mathrm{Ag} / \mathrm{ZnS}\end{array}$ & $11.9-13.3$ & 7.42-10.9 & $380-750$ & [183] \\
\hline $\mathrm{FTO} / \mathrm{c}-\mathrm{TiO}_{2} / \mathrm{mp}-\mathrm{TiO}_{2} / \mathrm{Al}_{2} \mathrm{O}_{3} / \mathrm{MAPbI}_{3}$-Carbon grid $/ \mathrm{WO}_{3}$ & 8.1 & 20 & $380-780$ & [184] \\
\hline $\begin{array}{l}\mathrm{FTO} / \mathrm{c}-\mathrm{TiO}_{2} / \mathrm{mp}^{-\mathrm{TiO}_{2}} / \mathrm{Al}_{2} \mathrm{O}_{3} / \text { graphene-PEDOT:PSS/MAPbI} \\
\text { grid }\end{array}$ & $7.2,11.6$ & 26,20 & $380-780$ & [185] \\
\hline
\end{tabular}

\subsection{Upscaling Stature of PSCS}

Scaled up of the PSC is essential to implement them for their on-site application. However, scaling up PSC exerts as a hugely challenging issue specifically for the fabrication technology, large-scale material development and sequential right tracklayer deposition. Scaling up often reduce the efficiency of the overall system. Therefore, the development of large-scale PSC is a big challenge in terms of both the cost-effectiveness and necessary longevity. In this regard, sheet-to-sheet and roll-to-roll deposition methods stand out as a suitable scaling up methods for large-scale PSC fabrication. Reduction of bulk defect recombination and electric leakage followed by adjusting its bandgap and increasing the charge generation are the crucial factors that require to be perfectly attained in large-scale PSCs, which is undoubtedly a challenging task. There are many attempts that have been made for upscaling of PSCs, providing importance on high efficiency and excellent stability too. However, increasing the cell dimension also drops the power conversion. For example, cell dimension increment from 0.12 to $1.1 \mathrm{~cm}^{2}$ resulted $11.5 \%$ reduction of efficiency [186]. PSC $10.1 \mathrm{~cm}^{2}$ modules exhibited a PCE of $10.4 \%$, which was enhanced to $13.3 \%$ for reducing the area [187]. A $198 \mathrm{~cm}^{2}$ area based PSC offered PCE of 6.6\% [188] while Gardner et al. (2016) [189] achieved only 4.3\% PCE for a cell having an active area of $100 \mathrm{~cm}^{2}$. However, Hu et al. (2017) achieved a mesoscopic $100 \mathrm{~cm}^{2}$ area PSC having PCE of $10.4 \%$ [190]. 
Another work showed fully printable large-area $7 \mathrm{~m}^{2}$ perovskite panels made by $10 \%$ efficient $10 \times 10$ $\mathrm{cm}^{2}$ perovskite modules [190]. Weihua Solar manufactured large-area $45 \times 65 \mathrm{~cm}^{2}$ modules by using $10.6 \%$ efficient $5 \times 5 \mathrm{~cm}^{2}$ cells [191]. Recently, one $703 \mathrm{~cm}^{2}\left(24.15 \times 29.10 \mathrm{~cm}^{2}\right)$ large size with excellent efficiency Perovskite was fabricated where crystal properties were controlled during the fabrication of the crystal growth process [192]. Microquanta successfully fabricated a $200 \times 800 \mathrm{~cm}^{2}$ module with a PCE of $14.24 \%$ [193]. Very recently, the Panasonic electronics manufacturer has produced a lightweight $30 \times 30 \mathrm{~cm}^{2}$ perovskite with an efficiency of $16.09 \%$ [194].

\section{Advancement of PSCs for BIPV}

Building integration of PSCs is one of the most holistic approaches as transparent and semi-transparent PSCs are possible by tuning the material thickness and bandgap. BIPV may hold the potential to increase PSC technology suitable space on buildings. Uniform transparency over the entire device area makes PSC a very engaging for BIPV applications, which combine the production of green energy and esthetic architectural features of elements that are part of the green environment for human habitat. Integration of PSC in BIPV is still a less-explored work compared to the other PVs. The transparency-efficiency tradeoff can be considered for a proper design of BIPV applications where transparency and efficiency both represent design parameters. Figure 6 highlights the major required characteristics for BIPV integration in the less energy-hungry building using PSCs.

- Outdoor stability;

- Lightweight: the total mass of the cell does not strain the construction of the building;

- Semitransparency and;

- Low-scattered light: able to harvest solar energy also in shadowed areas or cloudy conditions that can bring up the PSC for a suitable BIPV employment.

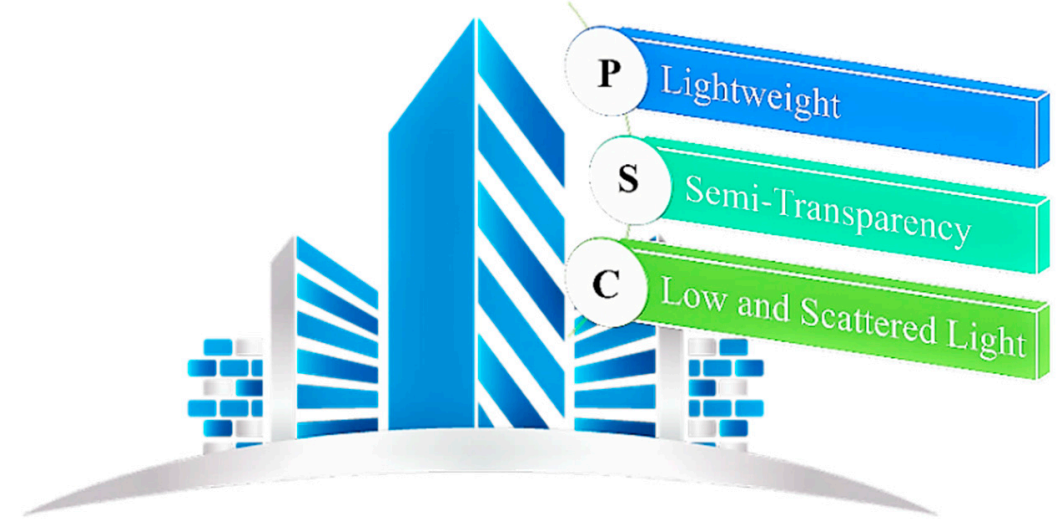

Figure 6. Schematic representation of the suitable PSC features for BIPV.

\subsection{Recent Progress of PSCs Integration in BIPV}

BIPV systems are promising for energy conscious building design techniques. Design considerations for BIPV systems must include the building's architecture, its location, any appropriate building and safety codes. Integration of PSC involves effective design for the local climate and environment and considering consolidated daylighting and photovoltaic collection. In this regard, various attempts have been promoted to employ PSC in BIPV application.

Bifacial colourful ST-PSCs in an n-i-p architecture using CuSCN as a hole transporting material, was developed by Wang et al. (2020), exhibits wide colourful tunability and excellent bifacial photovoltaic behaviour and emerging as a promising candidate for BIPV applications [195]. Martellotta et al. (2017) pointed out with particular reference to semi-transparent PV cells using amorphous silica (a-Si), and perovskite may have a significant impact on BIPV application. PSC with $42.4 \%$ transmission exhibited higher PCE (6.64\%) compared to lesser transparent (30.1\%) amorphous $\mathrm{Si}$ 
cell, which resulted in maximum efficiency of $4.80 \%$. Moreover, the authors claimed that the PSC offered a more balanced visual comfort behaviour compared to the a-Si device and produced electricity with different behaviours concerning solar radiation. This study offers the futuristic scope of PSCs integration as a potential substitute candidate for silicon solar cells for BIPV. Despite that, Aernouts et al. (2019) [196] demonstrates about the efficient structures and processes for reliable perovskite solar modules in BIPV facade application, with support of outdoor test results, which opens then the door for technology validation for a fully integrated product (Figure 7). The authors demonstrated a cost-effective, highly efficient $(>17 \%)$ perovskite-based $35 \times 35 \mathrm{~cm}^{2}$ module architecture having over 20 years of reliability.

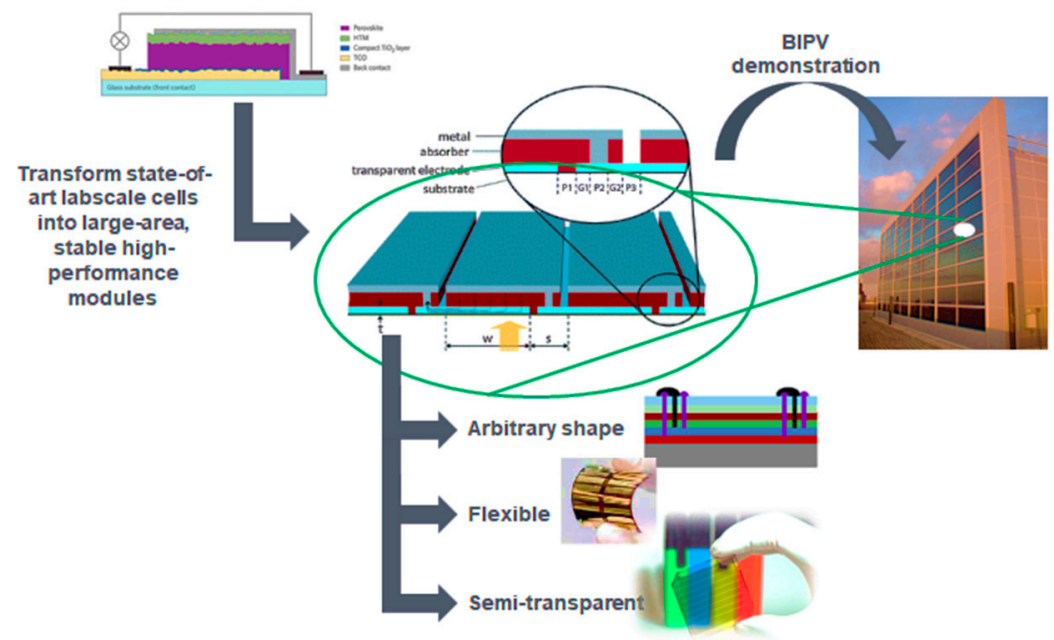

Figure 7. Schematic represents of efficient structures and processes for reliable PSC modules for BIPV application. Reproduced with permission [196].

Ghosh et al. (2019) developed carbon-based PSC having which had PCE of 8.13\%, 30\% average solar transmission and $20 \%$ average visible transmission, at the laboratory environment for BIPV application. In addition, daylighting and glare control analysis employing the subjective rating methods was investigated. For midday period of a typical bright sunny day at the location of the University of Exeter, Penryn ( $\left.50.16^{\circ} \mathrm{N}, 5.10^{\circ} \mathrm{W}\right)$, UK, high glare was observed [184]. Improved visual comfort is attainable while Perovskite PV windows are employed in a building by replacing solar control window [7]. Coloured PSC reflects light which is also potential for BIPV application as lowering the thermal gain comfortable indoor environment is achievable. Furthermore, reflected light reduces the possibility of overheating of the solar cell. The PSC developed by Zhang et al. (2015) was capable of tuning colour across the visible spectrum while maintained the high efficiency. This product is suitable for sustainable coloured BIPV architecture [197]. PSCs also changes its transmission in the presence of temperature, which is known as thermochromism. Transmission variation in the visible range for thermochromic (TC) perovskite is suitable for retrofit or newly glazed façade application [198]. Figure 8 shows a colour neutral PSC-BIPV, while amorphous Si cells absorb most of the blue-green radiation and appear as brown-orange [199].

Tandem structure of PSCs is attractive candidates where at the top [118] or the bottom silicon are stacked mechanically. Mechanically stacked silicon bottom cell PSC achieved a PCE of 23.9\% [200,201]. This is the highest achieved efficiency from the four-terminal tandem device. 

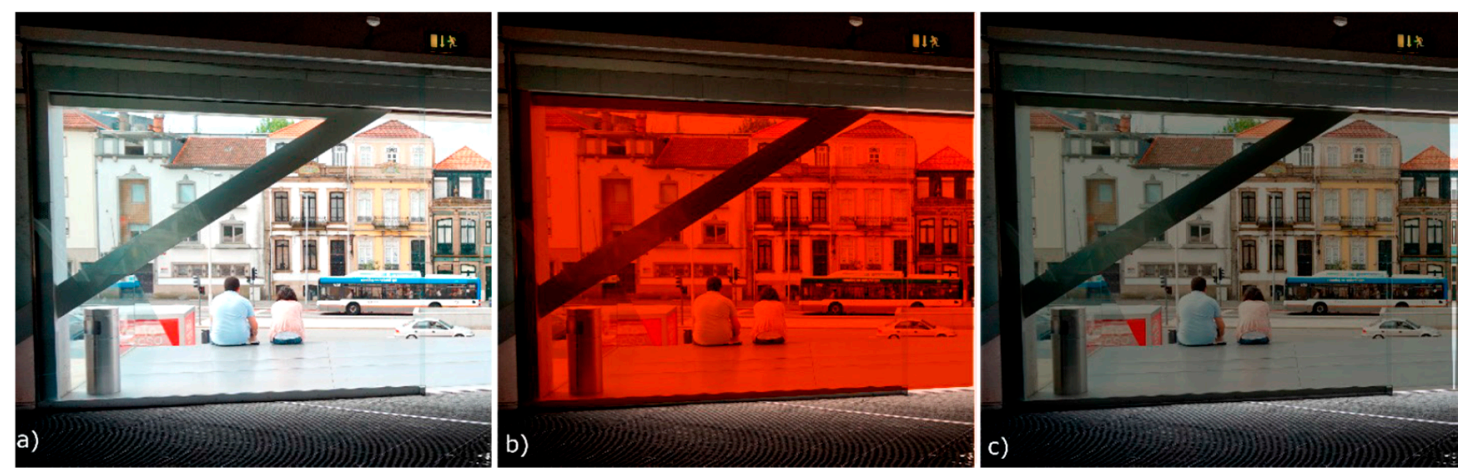

Figure 8. Simulation of the appearance of the different PV technologies applied to the glazing such as (a) baseline condition; (b) a-Si cell and (c) PSC. Reprinted with permission [199].

However, stability was encountered as the most challenging for PSC efforts, were given to characterize it at the outdoor condition. Of course, the low-cost and flexible manufacturing prospects of PSCs offers a desirable integration in the BIPV market. The flexible PSC modules laminated into a glass façade element, which was manufactured by Saule Technologies and installed in Skanska's Spark building in Warsaw, Poland [202]. The BIPV market expects tremendous growth from $€ 1$ billion in 2015 to $€ 6.3$ billion in 2022.

\subsection{Lightweight PSCs for BIPV}

Lightweight BIPV technology is essential for building integration especially retrofit the building. Hence flexible and wearable PV systems are gaining importance because of their potential application in building. Flexible PV indicates a reduced weight PV which can be quantified as specific power (watts/kilogram). Fabrication of flexible transparent PSC requires flexible transparent electrodes which should have high conductivity and excellent mechanical stability. Hence, the replacement of the conventional brittle electrodes is required [203,204]. In terms of flexibility consideration, the polymer substrates are considerable candidate due to cheaper and low-temperature solution processing. The inexpensive polymer substrates such as polyethene terephthalate (PET) and polyethylene naphthalate (PEN) have been found suitable to fabricate flexible PSCs [101].

Along with, the mechanical stability of the device is also essential to generate adequate power per weight for their utilization. The potential of reaching extremely high specific powers in PSC reporting $\sim 29.4 \mathrm{~W} \cdot \mathrm{g}^{-1}$ with only $12 \%$ efficient device as demonstrated by Kang et al. (2019) [205]. This value is orders of magnitude higher than what typically characterizes traditional crystalline Si cells lies in the range of $0.1-1 \mathrm{~W} \cdot \mathrm{g}^{-1}$ [206]. Notable performances of lightweight-based PSCs are summarized in Table 6.

Table 6. Significant reports on the performance of flexible PSCs *.

\begin{tabular}{cccc}
\hline Substrate & PCE (\%) & Power-per-Weight & Reference \\
\hline PAN foils-ITO $(1.3 \mu \mathrm{m})$ & 15.2 & $29.4 \mathrm{~W} / \mathrm{g}$ & {$[205]$} \\
\hline PET foil $(1.4 \mu \mathrm{m})$ & 12 & $23 \mathrm{~W} / \mathrm{g}$ & {$[206]$} \\
\hline PET/Graphene $(20 \mu \mathrm{m})$ & 11.5 & $5 \mathrm{~W} / \mathrm{g}$ & {$[207]$} \\
\hline Ultrathin PET/Silver mesh $(57 \mu \mathrm{m})$ & 14 & $1.96 \mathrm{~kW} / \mathrm{kg}$ & {$[208]$} \\
\hline ITO-coated PET & 14.2 & $23.26 \mathrm{~W} / \mathrm{g}$ & {$[209]$} \\
\hline PET/Ag Nanowire $(17 \mu \mathrm{m})$ & 12.9 & $4.16 \mathrm{~W} / \mathrm{g}$ & {$[210]$} \\
\hline * PEN: Polyethylene naphthalate; PET: Polyethylene terephthalate; &
\end{tabular}




\subsection{Solar Ink-Based PSCs}

Solar paint can replace the high-temperature annealing processed fabrication for high-efficiency PSCs [211]. This process can further be improvised by addition of chemical steps to enhance the electronic inter-grain connectivity, which will enhance the conversion efficiency. The roll-to-roll fabrication process excels as a compatible technique in order to make large-scale PSCs. The roll-to-roll deposition techniques such as ink-jet printing, slot die coating, blade coating, spray coating, screen-printing, flexography, etc. are one of the most convenient processes to use the solar paints to fabricate PSCs in a large scale (Figure 9a,b) [201,212]. Having the advantage of large wafer substrates allowance, faster deposition technique, a highly scalable and cost-effectiveness of the overall process further provides the roll-on roll fabrication approach as one of the best solutions for large scale production [191,212]. Implementation of such solar paint-based protocol on a roll-to-roll cell manufacturing is now seeking attention. The solar paint can be applied in BIPV, where the photoanode can be directly painted on the walls or windows of a building. Solar paints are a class of thin-film technology in which it can be fabricated in the form of solution. This solution is applied on glass or plastic substrate by spraying or brushing to make a complete solar cell. Some of the most attractive features of PV paints are thin layer deposition, substrate availability, less waste during processing and non-fragile. The solar paint can be further directly applied in BIPV, where the ETL can be directly painted on the walls or windows of a building.

(a)

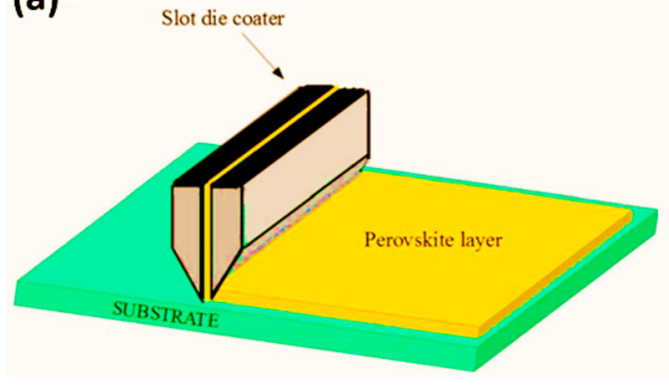

(b)

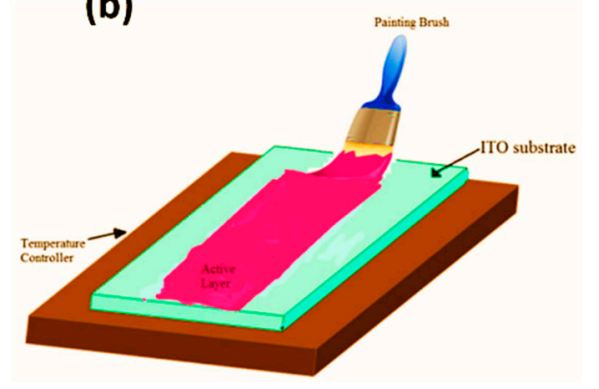

Figure 9. Perovskite layer deposition using (a) slot die coating, (b) brush painting techniques, for solar paint-based PSCs, respectively.

So far, different approaches such as additive inclusion, thermal annealing and different kind of precursors, were explored to control morphology, crystalline structure and moisture stability of perovskite. In combination with these strategies, the use of anti-solvent dripping during the deposition of perovskite precursors is widely exploited to obtain better film morphology and properties. Beside solvent toxicity, anti-solvent dripping is hardly compatible with scalable productions technologies; therefore, strategies to control the perovskite film formation in one-step and solvent dripping free is a technological challenge. The spinning in the typical perovskite process flings away most of the liquid, so a better approach is therefore required. The acetonitrile/methylamine system is unusual for a few reasons: First, it utilizes methylamine as the Pb-alkylamine former, thereby reducing the chance of impurities and over passivation [213]. The acetonitrile system is shelf-stable for long periods. Acetonitrile as a solvent also has many desirable properties for high-speed manufacturing such as low boiling point, low viscosity and low surface tension relative to the commonly used dimethylformamide (DMF) [214], dimethyl sulfoxide (DMSO) [154] and N-Methyl-2-pyrrolidone (NMP) [215] systems. Instead of using the toxic solvents, starch biopolymer exploits as a rheological modifier to tailor the viscosity of perovskite precursor solutions to obtain a stable ink for uniform perovskite thin films [216]. TCs have attracted broad interest due to their simple reversible mechanism of using thermal energy for switching transmittance. Typically, commercially available TCs are liquid crystals and leuco dyes and recently vanadium dioxide. The crystallization temperature in inverse temperature crystallization depends on the halogen constituent of the perovskite. This observation inspired to combine the tunable 
optical properties and unusual crystallization processes of perovskites to design a facile synthesis of TC inks that realize smart windows with more extensive chromatic variation than thought possible in hybrid perovskites [217,218].

\subsection{Zero-Energy Building Approach of PSCs in BIPV}

Significant insights were gained while theoretical approaches based on $\mathrm{MAPbI}_{3}$ perovskite was employed $[57,219,220]$. The modelling studies of such PSCs include formability of the perovskite structure, effect of reduced structural dimensionality and $\mathrm{Pb}$-ion insertion, which can pave way further improvement of perovskite development. On the other hand, features like Rashba effect [221], the ferroelectric effect [222], carrier localization effect [223], ion transport and halogen atom inclusion [224], provides high optoelectronics property modulation for PSCs. Alternatively, achieving zero energy is an ambitious yet increasingly achievable goal, i.e., gaining momentum across geographic regions and markets [225]. Reduced energy consumption of PSCs, therefore, makes it simpler and less expensive to meet the building's energy needs for BIPV. Figure 10 highlights about a scheme of all these features, which need to be co-inside to develop a zero-energy building using PSC.

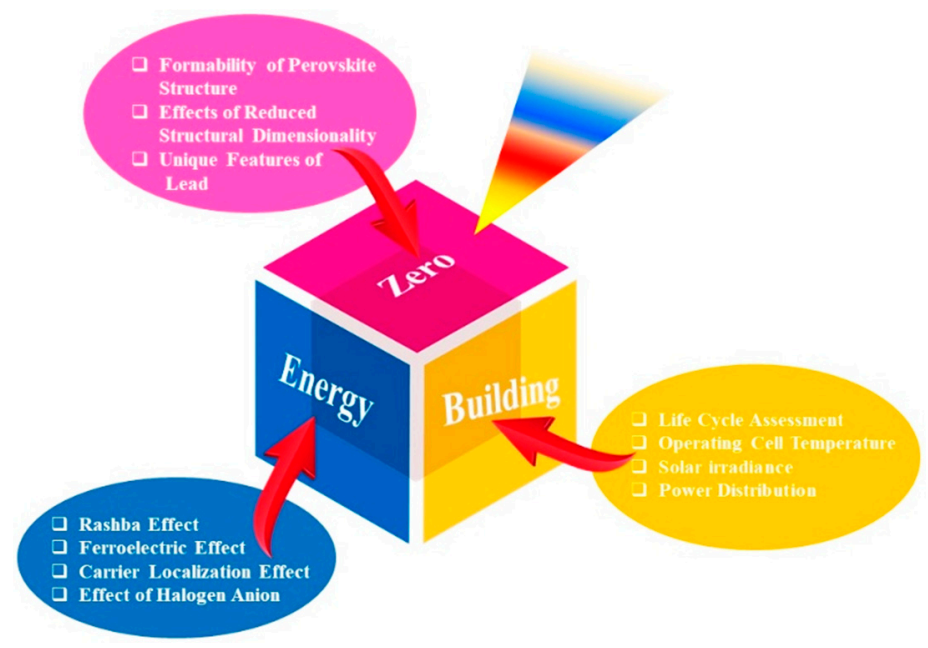

Figure 10. Scheme of the PSC-integrated BIPV modelling study for zero-energy building development.

Reports are available on the top floor of the apartment, which has been investigated by using the $4 \times 4 \times 3 \mathrm{~m}^{3}$ single box model covered by PSCs [226-230]. The hourly energy gains from the rooftops and façades are calculated based on the measured angle-dependent performance of the solar cells and the hourly solar intensities. Assoa et al. (2017) attempted different approaches, including a linear model, lumped elements models and models that make use of commercial software solvers for rooftop BIPV modelling study [227]. The forecasted solar irradiance $7 \mathrm{~kW}$ solar PV system for net-zero building was evaluated in India climate [228]. One the other hand, Poulek et al. (2015) rationalized an annual estimation of temperature difference $3.2 \mathrm{~K}$ and $3.5 \%$ in energy production between roof integrated and free-standing PV panels through thermal models [229]. Recently, Walker et al. (2019) reported a thin-film CIGS module with longitudinal cell direction to outperform modules with orthogonal cell direction by up to $8 \%$. The thin-film CIGS modules on the scale of one module under partial shading conditions, one curved module and two connected modules [226]. The model was validated using recorded experimental data over an entire year. Recently, Gong et al. (2019) used the single box model of $4 \times 4 \times 3 \mathrm{~m}^{3}$ which converted $35 \%$ solar radiation to electricity is a promising solution for distributed power generation and the zero-energy residential building in the Wuhan urban area in China [231].

\section{Future of PSCs Based BIPV}

Concerning the present status of PV technologies, improvements in several areas are required, such as conversion efficiency, cost, durability and sustainability. With the emergence and rapid growth 
of nanotechnology, harnessing of the novel nanomaterials for PSCs has increased over the past two decades, and the process of discovery and invention is continuing.

The calculation of LCOE, i.e., Levelized cost of electricity signifies that the total cost per unit of electricity generated over the lifetime from the PSC system is competitive compared to other available PV technology $[207,232,233]$. The "Golden Triangle" model indicates about the performance, durability and cost of the PV system, as shown in Figure 11a. As an example, Liu et al. (2018) developed the PSC having a PCE of $19.1 \% \pm 0.4 \%$ with good reproducibility. The un-encapsulated PSCs exhibit above $1600 \mathrm{~h}$ lifetime under continuous dry nitrogen environment. This study recommends a suitable example of the "golden triangle" report for a PSC in terms of their conversion rate of sunlight into electricity must be high, inexpensive to produce, and possess a long lifespan [207]. In the case of BIPV implementation, the functionality depends on building's design, durability, geographical position, safety and maintenance as shown in Figure 11b, which can control the effective justice to the golden triangle theory.

(a)

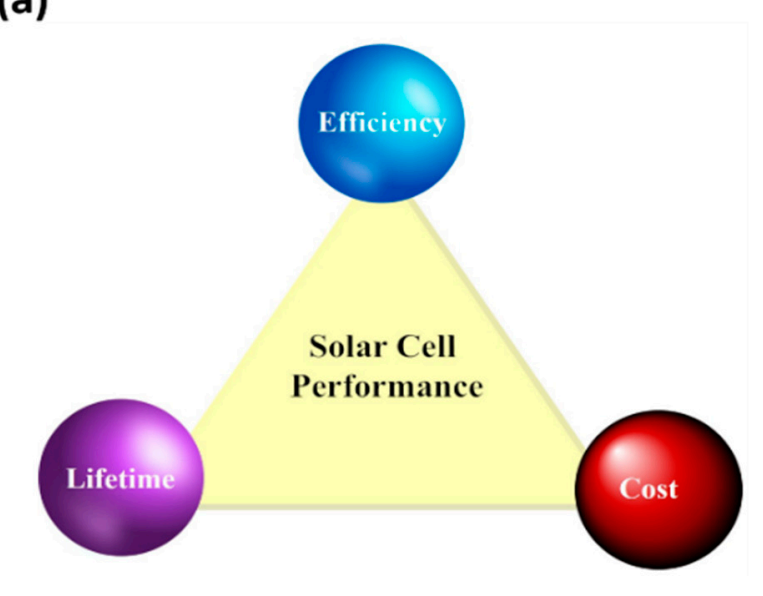

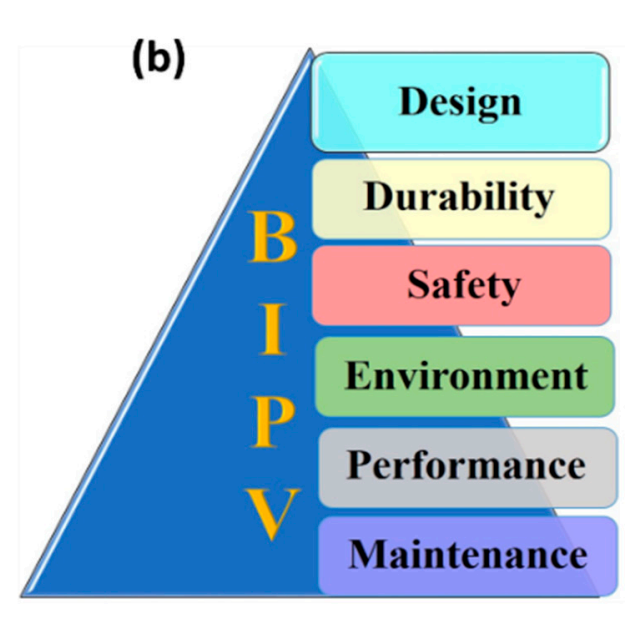

Figure 11. (a) Golden triangle of solar cells bonded with the cost, efficiency and lifetime parameters and (b) parameters for PV building integration.

\subsection{Scope of PSCs in Building Energy Storage Application}

It is advantageous to design PSC-electrochemical storage hybrid devices to store the power as achieved form PSC. In this regard, PSC introduces as a window frame around the electrochromic glass. This can make solid-state electrochromic batteries in smart windows. In such a configuration, the solar-cell window frame harvests electricity and provide power to the electrochromic glass [234-237]. Table 7 summarizes performances of various significant PSCs for electrochemical storage hybrid devices. Xia et al. (2016) demonstrated a solid-state electrochromic battery made with $\mathrm{MAPbI}_{3}$-based PSC and $\mathrm{WO}_{3}$-based electrochromic device, which exhibits reasonable cycling stability with a capacity of $65 \mathrm{~mA} \cdot \mathrm{h} \cdot \mathrm{g}^{-1}$ at $1 \mathrm{~A} \cdot \mathrm{g}^{-1}$ after 2500 cycles with retention of $86.7 \%$ [45]. This result indicates the successful implantation of PSC in electrochromic devices. 
Table 7. Significant performance of various PSCs for electrochemical storage hybrid devices *.

\begin{tabular}{|c|c|c|c|c|}
\hline Perovskite & Storage Active Layer & $\begin{array}{c}\text { Device } \\
\text { Performance }\end{array}$ & Storage Performance & Reference \\
\hline $\mathrm{MAPbI}_{3}$ & $\begin{array}{c}\text { Bacterial cellulose } \\
\text { membrane/Polypyrrole/MWCNT }\end{array}$ & $\begin{array}{l}\text { Efficiency: } 13.6 \% \\
\mathrm{~V}_{\mathrm{OC}}: 0.98 \mathrm{~V}\end{array}$ & $\begin{array}{c}\text { Capacitance: } 572 \mathrm{mF} \cdot \mathrm{cm}^{-2} \\
\left(1.0 \mathrm{~mA} \cdot \mathrm{cm}^{-2}\right) \\
\text { SE: } 49 \%\end{array}$ & [238] \\
\hline $\mathrm{MAPbI}_{3}$ & $\begin{array}{l}\text { Copper hydroxide } \\
\text { nanotubes/ } / \mathrm{MnO}_{2}\end{array}$ & $\begin{array}{l}\text { Efficiency: } 10.41 \% \\
\text { V }_{\text {OC }}: 0.96 \mathrm{~V}\end{array}$ & $\begin{array}{c}\text { Capacitance: } 37.93 \mathrm{mF} \cdot \mathrm{cm}^{-2} \\
\left(1.0 \mathrm{~mA} \cdot \mathrm{cm}^{-2}\right) \\
\text { Energy Density: } 3.36 \\
\mathrm{~mW} \cdot \mathrm{h} \cdot \mathrm{cm}^{-2}, \\
\text { Power Density } 74.02 \\
\mathrm{~mW} \cdot \mathrm{cm}^{-2}, \\
\mathrm{SE}, 67 \%\end{array}$ & [239] \\
\hline $\mathrm{MAPbI}_{3}$ & $\begin{array}{l}\text { Carbon-supported } \\
\text { graphene/PEDOT }\end{array}$ & $\begin{array}{l}\text { Efficiency: } 8.65 \% \\
\text { V }_{\text {OC }}: 1 \mathrm{~V}\end{array}$ & $\begin{array}{c}\text { Capacitance: } 388 \mathrm{mF} \cdot \mathrm{cm}^{-2} \\
\left(1.0 \mathrm{~mA} \cdot \mathrm{cm}^{-2}\right), \\
\text { Energy Density: } 0.18 \\
\mathrm{~W} \cdot \mathrm{h} \cdot \mathrm{cm}^{-2}\end{array}$ & [240] \\
\hline $\mathrm{CH}_{3} \mathrm{NH}_{3} \mathrm{PbI}_{3-\mathrm{x}} \mathrm{C}_{\mathrm{lx}}$ & $\mathrm{WO}_{3}$ & $\begin{array}{l}\text { Efficiency: } 8.25 \% \\
\text { V }_{\text {OC: }}: 0.98 \mathrm{~V}\end{array}$ & $\begin{array}{c}\text { Co-anode (co-cathode) } \\
\text { Energy Density: } 13.4 \text { (24.5) } \\
\mathrm{mW} \cdot \mathrm{h} \cdot \mathrm{cm}^{-2} \\
\text { Power Density: } 187.6 \\
\text { (377.0) } \mathrm{mW} . \mathrm{m}^{-2} \\
\text { Capacitance: } 286.8 \text { (430.7) } \\
\text { F.m }{ }^{-2}\end{array}$ & [241] \\
\hline $\mathrm{MAPbI}_{3}$ & $\begin{array}{c}\text { Asymmetric: } \mathrm{TiO}_{2} \\
\text { Nanotubes and } \mathrm{MnO}_{2} / \\
\mathrm{Co}_{6} \mathrm{~S}_{8}\end{array}$ & $\begin{array}{l}\text { Efficiency: } 5.6 \% \\
V_{\mathrm{OC}}: 0.81 \mathrm{~V}\end{array}$ & $\begin{array}{c}\text { Capacitance: } 262.5 \mathrm{mF} \cdot \mathrm{cm}^{-2} \\
\left(0.5 \mathrm{~mA} \cdot \mathrm{cm}^{-2}\right), \text { SE: } 80 \%\end{array}$ & [242] \\
\hline $\mathrm{MA}_{1-\mathrm{y}} \mathrm{FA}_{\mathrm{y}} \mathrm{PbI}_{3-\mathrm{x}} \mathrm{Cl}_{\mathrm{x}}$ & $\begin{array}{l}\text { Anode: } \mathrm{Li}_{4} \mathrm{Ti}_{5} \mathrm{O}_{12} / \mathrm{rGO}, \\
\text { Cathode: Carbon }\end{array}$ & $\begin{array}{l}\text { Efficiency: } 14.01 \% \\
V_{\text {OC }}: 1.05 \mathrm{~V}\end{array}$ & $\begin{array}{c}\text { Energy Density: } 60 \mathrm{~W} \cdot \mathrm{h} \cdot \mathrm{kg}^{-1} \\
\text { SE: } 80 \%\end{array}$ & [243] \\
\hline$\left(\mathrm{C}_{6} \mathrm{H}_{9} \mathrm{C}_{2} \mathrm{H}_{4} \mathrm{NH}_{3}\right)_{2} \mathrm{PbI}_{4}$ & $\begin{array}{c}\left(\mathrm{C}_{6} \mathrm{H}_{9} \mathrm{C}_{2} \mathrm{H}_{4} \mathrm{NH}_{3}\right)_{2} \mathrm{PbI}_{4} / \\
\text { rGO/PVDF }\end{array}$ & Efficiency $^{\dagger}: 0.003 \%$ & Capacity: $410 \mathrm{~mA} \cdot \mathrm{h} \cdot \mathrm{g}^{-1}$ & [244] \\
\hline
\end{tabular}

On the other hand, $\mathrm{MAPbI}_{3}$-based series-connected PSCs directly charge lithium-ion batteries with a storage efficiency of $7.80 \%[245,246]$. Recently, Kin et al. (2020) have combined a high open-circuit voltage $\left(\mathrm{V}_{\mathrm{OC}}>1 \mathrm{~V}\right)$ PSC single cells with single-cell batteries via a direct-current-direct-current (DC-DC) boost converter to explore the feasibility of single-cell-to-single-cell integration of a single PSC with a Li-ion battery. They developed the PSCs charged Li-ion battery, in which, PSCs with a boost converter resulted in maximum overall efficiency of $9.9 \%$ and a high $14.9 \%$ solar to battery charging efficiency [247].

\subsection{Commercial and Building Integration Confronts of PSCs}

The outdoor stability of PSC is a crucial parameter for commercial application besides their high efficiency [248]. Despite the structural modification and various perovskite absorbers employment, the availability of sufficient quantities of precursors, cost-effective deposition and synthesis and easy process for a large-scale device with long-term stability are still the main challenges for PSCs (Figure 12) [249]. The crucial challenges that need to be overcome before PSCs can be considered a viable solution for extensive PV market deployment, primarily related to the stability of low bandgap perovskite. Nevertheless, the potential is unprecedented. However, there are ample of scope and opportunity to develop new and economically viable fabrication methods to develop an adequate PSC. 


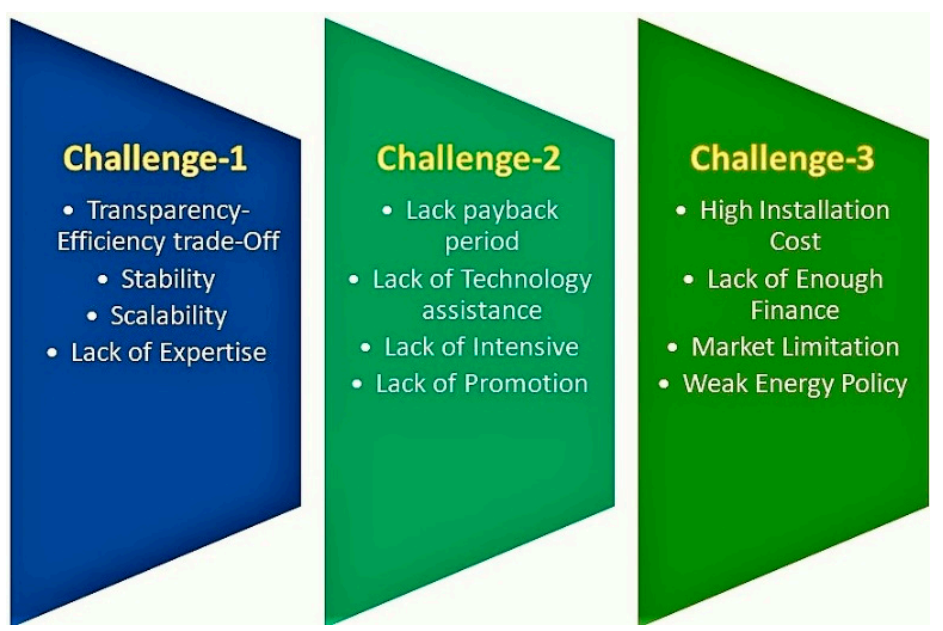

Figure 12. Challenges of a semi-transparent PSC for BIPV application.

Currently, the laboratory-scale record of PSC is at $>20 \%$ level, and commercial cells are $<9 \%$ PCE [250]. Stability of PSC is the main obstacle for commercialization as currently, best PSC shows one-year lifetime, which is much shorter than silicon-based 25 years stable PV [251]. Although, the current trending of PSC research signifies that the perovskite technology holds a great promise towards cost-effective manufacturing among other PV technologies. This can be achievable by variation in device architectures, incorporation of novel materials and synthesis approaches [252]. Use of such variations allows high charge transfer mobility and fewer grain boundaries between the layers to improve the performance. Despite fundamental research, synergies between environmental, socioeconomic and regional approaches are needed for perovskite research.

For the BIPV industry, the major challenge is the lack of standards [253]. There are no international standard rules for integration of PV technology into a building. Most often, the engaging parameters are PV inclination, orientation and occupant comfort. However, there are electrical cables involved for BIPV and the other electronic components [254]. Besides, Perovskite integrated into a building in northern latitude place where snow and rain are the most common phenomenon that should be considered before integration $[255,256]$. In the case of a hot climate and dust environment, how this technology will perform can be a significant investigating area before building integration [257-263] that must be a vital fact when considering PSC integration in BIPV.

Moreover, the fire safety norms for PSC-based BIPV should also be evaluated $[264,265]$. Therefore, PSC emerges as a possible candidate for BIPV application. In contrast, lack of proper building adaptive policy and stability challenges retard the PSC integration for BIPV.

\section{Perspective and Discussion}

Plenty of successful demonstrations of PSCs at low temperature and ambient condition processes on flexible substrates are available that can ease the fabrication process. The $\mathrm{MAPbI}_{3}$-based perovskite interplays various inter-structural physicochemical interactions with the different components of the perovskites device and generate excellent optoelectronic properties for PV applications [266]. For commercialization, use of toxic Pb element should be monitored by following the Restriction of Hazardous Substances (RoHS) criteria made by the European Union [267]. There is a drive to replace $\mathrm{Pb}$ with $\mathrm{Sn} / \mathrm{Cs}$, which is less toxic. Nevertheless, its natural oxidation creates $\mathrm{Sn}^{4+}$ and low electron mobility of $\mathrm{Cs}^{2+}$ that originates a metal-like behaviour in the semiconductor, which lowers the photovoltaic performance. The high-efficiency evaluation of PSC is now giving robust and stiff competition to firstand second-generation solar cells. The positive inherent features of PSCs like conformability, flexibility, workability under low-light conditions, and more straightforward integration possibility in buildings as PV windows will strengthen their market entry. 
A proper forecast of future energy yield is also required from the investors to make a successful integration of PSC in BIPV. This cannot be accurately achieved with only obtained STC data. Furthermore, as electricity infrastructure transforms towards smart grids, understanding variability in PV energy production will become a significant component in the design and optimization of energy exchange and storage at all temporal and spatial scales. Within this framework, the findings on the different energy yields obtained under STC and real-life temperature and irradiance data are of crucial importance [268-270]. Various PV companies such as Oxford PV, GreatCell Energy, Solar Cube, Toshiba, Frontier Energy Solution, Microquanta Semiconductor, Hunt Perovskite Technologies, Swift Solar, Sekisui Chemical, Irish Photovoltaics, Panasonic, Saule Technologies, etc. are already manufacturing large-scale PVs module [27]. Constant research activities are going on, and combined efforts from both industry and research labs are in progress to scaling-up of PSCs. It is expected that in near future performance gap will be minimal between laboratory and industrial modules. Cost per kilowatt-hour is also an essential parameter, which is dominated by the efficiency and lifetime of PV systems. Simple fabrication and material formulation anticipate less production cost of PSC compare to conventional PV technologies. The lower production cost and highly durable is more sustainable and makes the PSCs commercially competitive. The crucial challenges that need to be overcome before all-perovskite multi-junctions can be considered a viable solution ready for high-value market deployment, primarily related to the stability of low bandgap perovskite. Many scientific articles and academic studies describe the cost analysis to manufacture the PSC in BIPV technology once it is at scale. Unfortunately, there is still a lack of research to address the actual cost figure and factors affecting economies of scale for the PSC integration in BIPV. Additionally, other routes more towards customization and facilitation of integration are to be opened. Further, to besides the research and development challenges, it is necessary to address other technological aspects for PSCs integration in BIPV, which are:

- Improvement of the Perovskite technology, by increasing the stability and efficiency and reliability;

- Reduction of negative life cycle environment cost, operation and maintenance cost;

- Reduce the technological risks and develop new capabilities for improved components and systems

A reliable simulation tool is required to predict the manufacturing cost of these modules under real situation is essential. We need to have a plan as to how we get the material and the technology to scale. Thus, are we going to have commercialization of PSC in BIPV on tomorrow? The answer is no, not yet. However, we are getting closure to reach our target every day.

\section{Conclusions}

In summary, understanding of the underlying photo-physical, interfacial energy alignment and electronic interface structure and charge-transfer phenomenon will further help improving device structures and better selection of materials. PSC holds great promise for addressing our energy concerns. Long-term poor stability is the major issue with PSCs; however, progress has been made in the manufacturing of more giant cells as well as modules, which is indispensable for commercialization of the technology. Stability improvement of the PSC requires an interdisciplinary research approach to explore new stable materials by selecting the choice of electrodes, barrier layers, charge transport layers and encapsulation strategies. Several approaches are underway in understanding many critical issues related to the fundamental physiochemical characteristics of each component in PSC and to enhance the stability. Besides, there is a lack of proper resources to perceive the value of esthetic designs and a suitable module for building adaptive PSC. Still, the discussed characteristics may help mitigate the disadvantages of higher prices and excels more opportunity that is significant for PSCs. Tandem perovskite can be a solution for a highly stable system. The continued research and development within PSCs materials and BIPV technologies will yield a better solution for in future. In this present study, we present the opportunities for PSCs towards considerable variation in the available BIPV 
research. We have made an effort on the current situation of PSCs research and the crucial factor associated with it to integrate them for BIPV application.

Author Contributions: Conceptualization, A.G., methodology, A.R.; A.G., investigation, A.G., A.R., S.B., resources, A.R., A.G., S.B., writing—original draft preparation, A.R.; A.G., S.B., writing-review and editing, A.R., A.G., S.B., supervision, A.G., S.S., T.K.M., project administration, A.G., S.S., T.K.M., funding acquisition, A.G., S.S., T.K.M. All authors have read and agreed to the published version of the manuscript.

Funding: This research received no external funding.

Acknowledgments: S.B. acknowledges the College of Engineering, Mathematics and Physical Sciences, the University of Exeter for his $\mathrm{PhD}$ fellowship.

Conflicts of Interest: The authors declare no conflicts of interest.

\section{References}

1. Selvaraj, P.; Ghosh, A.; Mallick, T.K.; Sundaram, S. Investigation of semi-transparent dye-sensitized solar cells for fenestration integration. Renew. Energy 2019, 141, 516-525. [CrossRef]

2. Ghosh, A.; Norton, B.; Duffy, A. First outdoor characterisation of a PV powered suspended particle device switchable glazing. Sol. Energy Mater. Sol. Cells 2016, 157, 1-9. [CrossRef]

3. Ghosh, A.; Norton, B. Optimization of PV powered SPD switchable glazing to minimise probability of loss of power supply. Renew. Energy 2019, 131, 993-1001. [CrossRef]

4. Ghosh, A.; Norton, B. Durability of switching behaviour after outdoor exposure for a suspended particle device switchable glazing. Sol. Energy Mater. Sol. Cells 2017, 163, 178-184. [CrossRef]

5. Ghosh, A.; Norton, B.; Duffy, A. Measured thermal \& daylight performance of an evacuated glazing using an outdoor test cell. Appl. Energy 2016, 177, 196-203. [CrossRef]

6. Ghosh, A.; Norton, B.; Duffy, A. Behaviour of a SPD switchable glazing in an outdoor test cell with heat removal under varying weather conditions. Appl. Energy 2016, 180, 695-706. [CrossRef]

7. Cannavale, A.; Ayr, U.; Martellotta, F. Energetic and visual comfort implications of using perovskite-based building-integrated photovoltaic glazings. Energy Procedia 2017, 126, 636-643. [CrossRef]

8. Jelle, B. Building Integrated Photovoltaics: A Concise Description of the Current State of the Art and Possible Research Pathways. Energies 2015, 9, 21. [CrossRef]

9. Osseweijer, F.J.; Hurk, L.B.V.D.; Teunissen, E.J.; Van Sark, W. A comparative review of building integrated photovoltaics ecosystems in selected European countries. Renew. Sustain. Energy Rev. 2018, 90, 1027-1040. [CrossRef]

10. Vasiliev, M.; Nur-E-Alam, M.; Alameh, K. Recent Developments in Solar Energy-Harvesting Technologies for Building Integration and Distributed Energy Generation. Energies 2019, 12, 1080. [CrossRef]

11. Heinstein, P.; Ballif, C.; Perret-Aebi, L.-E. Building Integrated Photovoltaics (BIPV): Review, Potentials, Barriers and Myths. Green 2013, 3, 125-156. [CrossRef]

12. Haegel, N.M.; Atwater, H.; Barnes, T.; Breyer, C.; Burrell, A.; Chiang, Y.-M.; De Wolf, S.; Dimmler, B.; Feldman, D.; Glunz, S.; et al. Terawatt-scale photovoltaics: Transform global energy. Science 2019, 364, 836-838. [CrossRef]

13. Karthick, A.; Murugavel, K.K.; Ghosh, A.; Sudhakar, K.; Ramanan, P. Investigation of a binary eutectic mixture of phase change material for building integrated photovoltaic (BIPV) system. Sol. Energy Mater. Sol. Cells 2020, 207, 110360. [CrossRef]

14. Karthick, A.; Ramanan, P.; Ghosh, A.; Stalin, B.; Kumar, R.V.; Baranilingesan, I. Performance enhancement of copper indium diselenide photovoltaic module using inorganic phase change material. Asia-Pac. J. Chem. Eng. 2020, e2480. [CrossRef]

15. K, P.R.; Gupta, M.V.N.S.; Nundy, S.; Karthick, A.; Ghosh, A. Status of BIPV and BAPV System for Less Energy-Hungry Building in India-A Review. Appl. Sci. 2020, 10, 2337. [CrossRef]

16. Ghosh, A.; Norton, B.; Duffy, A. Measured overall heat transfer coefficient of a suspended particle device switchable glazing. Appl. Energy 2015, 159, 362-369. [CrossRef]

17. Ghosh, A.; Norton, B. Advances in switchable and highly insulating autonomous (self-powered) glazing systems for adaptive low energy buildings. Renew. Energy 2018, 126, 1003-1031. [CrossRef] 
18. Soebarto, V.; Zhang, H.; Schiavon, S. A thermal comfort environmental chamber study of older and younger people. Build. Environ. 2019, 155, 1-14. [CrossRef]

19. Zhang, F.; De Dear, R.; Hancock, P. Effects of moderate thermal environments on cognitive performance: A multidisciplinary review. Appl. Energy 2019, 236, 760-777. [CrossRef]

20. López-Pérez, L.; Flores-Prieto, J.; Ríos-Rojas, C. Adaptive thermal comfort model for educational buildings in a hot-humid climate. Build. Environ. 2019, 150, 181-194. [CrossRef]

21. Ghosh, A.; Sundaram, S.; Mallick, T.K. Investigation of thermal and electrical performances of a combined semi-transparent PV-vacuum glazing. Appl. Energy 2018, 228, 1591-1600. [CrossRef]

22. Ghosh, A.; Sundaram, S.; Mallick, T.K. Colour properties and glazing factors evaluation of multicrystalline based semi-transparent Photovoltaic-vacuum glazing for BIPV application. Renew. Energy 2019, 131, 730-736. [CrossRef]

23. AlRashidi, H.; Ghosh, A.; Issa, W.; Sellami, N.; Mallick, T.; Sundaram, S. Thermal performance of semitransparent CdTe BIPV window at temperate climate. Sol. Energy 2020, 195, 536-543. [CrossRef]

24. AlRashidi, H.; Issa, W.; Sellami, N.; Ghosh, A.; Mallick, T.K.; Sundaram, S. Performance assessment of cadmium telluride-based semi-transparent glazing for power saving in façade buildings. Energy Build. 2020, 215, 109585. [CrossRef]

25. AlRashidi, H.; Ghosh, A.; Issa, W.; Sellami, N.; Mallick, T.; Sundaram, S. Evaluation of solar factor using spectral analysis for CdTe photovoltaic glazing. Mater. Lett. 2019, 237, 332-335. [CrossRef]

26. Roy, A.; Ghosh, A.; Bhandari, S.; Sundaram, S.; Mallick, T.K. Realization of Poly(methyl methacrylate)-Encapsulated Solution-Processed Carbon-Based Solar Cells: An Emerging Candidate for Buildings' Comfort. Ind. Eng. Chem. Res. 2020, 59, 11063-11071. [CrossRef] [PubMed]

27. Roy, P.; Sinha, N.K.; Tiwari, S.; Khare, A. A review on perovskite solar cells: Evolution of architecture, fabrication techniques, commercialization issues and status. Sol. Energy 2020, 198, 665-688. [CrossRef]

28. Roy, A.; Ghosh, A.; Bhandari, S.; Selvaraj, P.; Sundaram, S.; Mallick, T.K. Color Comfort Evaluation of Dye-Sensitized Solar Cell (DSSC) Based Building-Integrated Photovoltaic (BIPV) Glazing after 2 Years of Ambient Exposure. J. Phys. Chem. C 2019, 123, 23834-23837. [CrossRef]

29. Lucera, L.; Machui, F.; Schmidt, H.; Ahmad, T.; Kubis, P.; Strohm, S.; Hepp, J.; Vetter, A.; Egelhaaf, H.-J.; Brabec, C. Printed semi-transparent large area organic photovoltaic modules with power conversion efficiencies of close to $5 \%$. Org. Electron. 2017, 45, 209-214. [CrossRef]

30. ORegan, B.; Gratzel, M. A Low-Cost, High-Efficiency Solar Cell Based on Dye-Sensitized Colloidal TiO 2 Films. Nature 1991, 353, 737-739. [CrossRef]

31. Duan, J.; Xu, H.; Sha, W.E.I.; Zhao, Y.; Wang, Y.; Yang, X.; Tang, Q. Inorganic perovskite solar cells: An emerging member of the photovoltaic community. J. Mater. Chem. A 2019, 7, 21036-21068. [CrossRef]

32. Xu, Q.; Yang, D.; Lv, J.; Sun, Y.-Y.; Zhang, L. Perovskite Solar Absorbers: Materials by Design. Small Methods 2018, 2, 1700316. [CrossRef]

33. Park, N. Research Direction toward Scalable, Stable, and High Efficiency Perovskite Solar Cells. Adv. Energy Mater. 2020, 10, 1-14. [CrossRef]

34. Stoumpos, C.C.; Kanatzidis, M.G. The Renaissance of Halide Perovskites and Their Evolution as Emerging Semiconductors. Acc. Chem. Res. 2015, 48, 2791-2802. [CrossRef]

35. Niu, G.; Guo, X.; Wang, L. Review of recent progress in chemical stability of perovskite solar cells. J. Mater. Chem. A 2015, 3, 8970-8980. [CrossRef]

36. Gao, P.; Grätzel, M.; Nazeeruddin, M.K. Organohalide lead perovskites for photovoltaic applications. Energy Environ. Sci. 2014, 7, 2448-2463. [CrossRef]

37. Green, M.A.; Ho-Baillie, A.W.Y.; Snaith, H.J. The emergence of perovskite solar cells. Nat. Photonics 2014, 8, 506-514. [CrossRef]

38. A decade of perovskite photovoltaics. Nat. Energy 2019, 4, 1. Available online: https://www.nature.com/ articles/s41560-018-0323-9 (accessed on 6 May 2020). [CrossRef]

39. Ansari, M.I.H.; Qurashi, A.; Nazeeruddin, M.K. Frontiers, opportunities, and challenges in perovskite solar cells: A critical review. J. Photochem. Photobiol. C Photochem. Rev. 2018, 35, 1-24. [CrossRef]

40. Jena, A.K.; Kulkarni, A.; Miyasaka, T. Halide Perovskite Photovoltaics: Background, Status, and Future Prospects. Chem. Rev. 2019, 119, 3036-3103. [CrossRef]

41. Seok, S.I.; Grätzel, M.; Park, N.-G. Methodologies toward Highly Efficient Perovskite Solar Cells. Small 2018, 14, e1704177. [CrossRef] [PubMed] 
42. Kojima, A.; Teshima, K.; Shirai, Y.; Miyasaka, T. Organometal halide perovskites as visible-light sensitizers for photovoltaic cells. J. Am. Chem. Soc. 2009, 131, 6050-6051. [CrossRef]

43. Tang, H.; He, S.; Peng, C. A Short Progress Report on High-Efficiency Perovskite Solar Cells. Nanosi. Res. Lett. 2017, 12, 410. [CrossRef] [PubMed]

44. NERL Best Research-Cell Efficiency Chart. Available online: https://www.nrel.gov/pv/cell-efficiency.html (accessed on 5 May 2020).

45. Minemoto, T.; Murata, M. Device modeling of perovskite solar cells based on structural similarity with thin film inorganic semiconductor solar cells. J. Appl. Phys. 2014, 116, 54505. [CrossRef]

46. Yang, W.S.; Noh, J.H.; Jeon, N.J.; Kim, Y.C.; Ryu, S.; Seo, J.; Seok, S.I. High-performance photovoltaic perovskite layers fabricated through intramolecular exchange. Science 2015, 348, 1234-1237. [CrossRef] [PubMed]

47. Deng, Y.; Dong, Q.; Bi, C.; Yuan, Y.; Huang, J. Air-Stable, Efficient Mixed-Cation Perovskite Solar Cells with $\mathrm{Cu}$ Electrode by Scalable Fabrication of Active Layer. Adv. Energy Mater. 2016, 6, e1600372. [CrossRef]

48. Yu, Y.; Wang, C.; Grice, C.R.; Shrestha, N.; Chen, J.; Zhao, D.; Liao, W.; Cimaroli, A.J.; Roland, P.J.; Ellingson, R.J.; et al. Improving the Performance of Formamidinium and Cesium Lead Triiodide Perovskite Solar Cells using Lead Thiocyanate Additives. ChemSusChem 2016, 9, 3288-3297. [CrossRef]

49. Saliba, M.; Matsui, T.; Seo, J.-Y.; Domanski, K.; Correa-Baena, J.-P.; Nazeeruddin, M.K.; Zakeeruddin, S.M.; Tress, W.; Abate, A.; Hagfeldt, A.; et al. Cesium-containing triple cation perovskite solar cells: Improved stability, reproducibility and high efficiency. Energy Environ. Sci. 2016, 9, 1989-1997. [CrossRef]

50. Zhao, J.; Zheng, X.; Deng, Y.; Li, T.; Shao, Y.; Gruverman, A.; Shield, J.; Huang, J. Is Cu a stable electrode material in hybrid perovskite solar cells for a 30-year lifetime? Energy Environ. Sci. 2016, 9, 3650-3656. [CrossRef]

51. Li, X.; Bi, D.; Yi, C.; Décoppet, J.-D.; Luo, J.; Zakeeruddin, S.M.; Hagfeldt, A.; Grätzel, M. A vacuum flash-assisted solution process for high-efficiency large-area perovskite solar cells. Science 2016, 353, 58-62. [CrossRef]

52. Yang, W.S.; Park, B.-W.; Jung, E.H.; Jeon, N.J.; Kim, Y.C.; Lee, D.U.; Shin, S.S.; Seo, J.; Kim, E.K.; Noh, J.H.; et al. Iodide management in formamidinium-lead-halide-based perovskite layers for efficient solar cells. Science 2017, 356, 1376-1379. [CrossRef] [PubMed]

53. Jung, E.H.; Jeon, N.J.; Park, E.Y.; Moon, C.S.; Shin, T.J.; Yang, T.-Y.; Noh, J.H.; Seo, J. Efficient, stable and scalable perovskite solar cells using poly(3-hexylthiophene). Natural 2019, 567, 511-515. [CrossRef] [PubMed]

54. Gao, X.-X.; Luo, W.; Zhang, Y.; Hu, R.; Zhang, B.; Züttel, A.; Feng, Y.; Nazeeruddin, M.K. Stable and High-Efficiency Methylammonium-Free Perovskite Solar Cells. Adv. Mater. 2020, 32, e1905502. [CrossRef]

55. OXFORDPV. Oxford PV Perovskite Solar Cell Achieves 28\% Efficiency. Available online: https://www. oxfordpv.com/news/oxford-pv-perovskite-solar-cell-achieves-28-efficiency (accessed on 5 May 2020).

56. Fujiwara, H. Almost 40\% Conversion Efficiency Predicted in New Perovskite Solar Cell. 2020. Available online: https:/www.advancedsciencenews.com/almost-40-conversion-efficiency-predicted-innew-perovskite-solar-cell/ (accessed on 31 January 2020).

57. Yin, W.-J.; Yang, J.-H.; Kang, J.; Yan, Y.; Wei, S.-H. Halide perovskite materials for solar cells: A theoretical review. J. Mater. Chem. A 2015, 3, 8926-8942. [CrossRef]

58. Nishigaki, Y.; Nagai, T.; Nishiwaki, M.; Aizawa, T.; Kozawa, M.; Hanzawa, K.; Kato, Y.; Sai, H.; Hiramatsu, H.; Hosono, H.; et al. Extraordinary Strong Band-Edge Absorption in Distorted Chalcogenide Perovskites. Sol. RRL 2020, 4. [CrossRef]

59. Dupre, O.; Niesen, B.; De Wolf, S.; Ballif, C. Field Performance versus Standard Test Condition Efficiency of Tandem Solar Cells and the Singular Case of Perovskites/Silicon Devices. J. Phys. Chem. Lett. 2018, 9, 446-458. [CrossRef]

60. Lee, S.-W.; Kim, S.; Bae, S.; Cho, K.; Chung, T.; Mundt, L.E.; Lee, S.; Park, S.; Park, H.; Schubert, M.C.; et al. UV Degradation and Recovery of Perovskite Solar Cells. Sci. Rep. 2016, 6, 38150. [CrossRef]

61. Fu, Q.; Tang, X.; Huang, B.; Hu, T.; Tan, L.; Chen, L.; Chen, Y. Recent Progress on the Long-Term Stability of Perovskite Solar Cells. Adv. Sci. 2018, 5, 1700387. [CrossRef]

62. Yi, Z.; Ladi, N.H.; Shai, X.; Li, H.; Shen, Y.; Wang, M.-K. Will organic-inorganic hybrid halide lead perovskites be eliminated from optoelectronic applications? Nanoscale Adv. 2019, 1, 1276-1289. [CrossRef]

63. Yang, J.; Siempelkamp, B.D.; Mosconi, E.; De Angelis, F.; Kelly, T.L. Origin of the Thermal Instability in CH3NH3PbI3 Thin Films Deposited on ZnO. Chem. Mater. 2015, 27, 4229-4236. [CrossRef] 
64. Conings, B.; Drijkoningen, J.; Gauquelin, N.; Babayigit, A.; D’Haen, J.; D’Olieslaeger, L.; Ethirajan, A.; Verbeeck, J.; Manca, J.V.; Mosconi, E.; et al. Intrinsic Thermal Instability of Methylammonium Lead Trihalide Perovskite. Adv. Energy Mater. 2015, 5, 1500477. [CrossRef]

65. Kwon, Y.S.; Lim, J.; Yun, H.-J.; Kim, Y.-H.; Park, T. A diketopyrrolopyrrole-containing hole transporting conjugated polymer for use in efficient stable organic-inorganic hybrid solar cells based on a perovskite. Energy Environ. Sci. 2014, 7, 1454. [CrossRef]

66. Philippe, B.; Park, B.-W.; Lindblad, R.; Oscarsson, J.; Ahmadi, S.; Johansson, E.M.J.; Rensmo, H. Chemical and Electronic Structure Characterization of Lead Halide Perovskites and Stability Behavior under Different Exposures-A Photoelectron Spectroscopy Investigation. Chem. Mater. 2015, 27, 1720-1731. [CrossRef]

67. Christians, J.A.; Herrera, P.A.M.; Kamat, P.V. Transformation of the Excited State and Photovoltaic Efficiency of $\mathrm{CH}_{3} \mathrm{NH}_{3} \mathrm{PbI}_{3}$ Perovskite upon Controlled Exposure to Humidified Air. J. Am. Chem. Soc. 2015, 137, 1530-1538. [CrossRef]

68. Aristidou, N.; Sanchez-Molina, I.; Chotchuangchutchaval, T.; Brown, M.; Martínez, L.; Rath, T.; Haque, S.A. The Role of Oxygen in the Degradation of Methylammonium Lead Trihalide Perovskite Photoactive Layers. Angew. Chem. Int. Ed. 2015, 54, 8208-8212. [CrossRef]

69. Wang, R.; Mujahid, M.; Duan, Y.; Wang, Z.-K.; Xue, J.; Yang, Y. A Review of Perovskites Solar Cell Stability. Adv. Funct. Mater. 2019, 29, 1-25. [CrossRef]

70. Leijtens, T.; Eperon, G.E.; Pathak, S.; Abate, A.; Lee, M.M.; Snaith, H.J. Overcoming ultraviolet light instability of sensitized $\mathrm{TiO}_{2}$ with meso-superstructured organometal tri-halide perovskite solar cells. Nat. Commun. 2013, 4, 2885. [CrossRef]

71. Liu, D.; Gangishetty, M.K.; Kelly, T.L. Effect of $\mathrm{CH}_{3} \mathrm{NH}_{3} \mathrm{PbI}_{3}$ thickness on device efficiency in planar heterojunction perovskite solar cells. J. Mater. Chem. A 2014, 2, 19873-19881. [CrossRef]

72. Wang, Q.; Chen, B.; Liu, Y.; Deng, Y.; Bai, Y.; Dong, Q.; Huang, J. Scaling behavior of moisture-induced grain degradation in polycrystalline hybrid perovskite thin films. Energy Environ. Sci. 2017, 10, 516-522. [CrossRef]

73. Ran, C.; Xua, J.; Gao, W.; Huang, C.; Dou, S.X. Defects in metal triiodide perovskite materials towards high-performance solar cells: Origin, impact, characterization, and engineering. Chem. Soc. Rev. 2018, 47, 4581-4610. [CrossRef]

74. Rong, Y.; Liu, L.; Mei, A.; Li, X.; Han, H. Beyond Efficiency: The Challenge of Stability in Mesoscopic Perovskite Solar Cells. Adv. Energy Mater. 2015, 5, 1501066. [CrossRef]

75. Supasai, T.; Rujisamphan, N.; Ullrich, K.; Chemseddine, A.; Dittrich, T. Formation of a passivating $\mathrm{CH}_{3} \mathrm{NH}_{3} \mathrm{PbI}_{3} / \mathrm{Pb}_{12}$ interface during moderate heating of $\mathrm{CH}_{3} \mathrm{NH}_{3} \mathrm{PbI}_{3}$ layers. Appl. Phys. Lett. 2013, 103, 183906. [CrossRef]

76. Kim, H.-S.; Seo, J.-Y.; Park, N.-G. Material and Device Stability in Perovskite Solar Cells. ChemSusChem 2016, 9, 2528-2540. [CrossRef] [PubMed]

77. Lian, J.; Lu, B.; Niu, F.; Zeng, P.; Zhan, X. Electron-Transport Materials in Perovskite Solar Cells. Small Methods 2018, 2, e1800082. [CrossRef]

78. Krishna, A.; Grimsdale, A.C. Hole transporting materials for mesoscopic perovskite solar cells-towards a rational design? J. Mater. Chem. A 2017, 5, 16446-16466. [CrossRef]

79. Seo, S.; Jeong, S.; Bae, C.; Park, N.-G.; Shin, H. Perovskite Solar Cells with Inorganic Electron- and Hole-Transport Layers Exhibiting Long-Term $(\approx 500 \mathrm{~h})$ Stability at $85^{\circ} \mathrm{C}$ under Continuous 1 Sun Illumination in Ambient Air. Adv. Mater. 2018, 30, e1801010. [CrossRef]

80. Kato, Y.; Ono, L.K.; Lee, M.; Wang, S.; Raga, S.R.; Qi, Y.B. Silver Iodide Formation in Methyl Ammonium Lead Iodide Perovskite Solar Cells with Silver Top Electrodes. Adv. Mater. Interfaces 2015, 2, 1500195. [CrossRef]

81. Amat, A.; Mosconi, E.; Ronca, E.; Quarti, C.; Umari, P.; Nazeeruddin, M.K.; Grätzel, M.; De Angelis, F. Cation-Induced Band-Gap Tuning in Organohalide Perovskites: Interplay of Spin-Orbit Coupling and Octahedra Tilting. Nano Lett. 2014, 14, 3608-3616. [CrossRef] [PubMed]

82. Koh, T.M.; Shanmugam, V.; Schlipf, J.; Oesinghaus, L.; Müller-Buschbaum, P.; Ramakrishnan, N.; Swamy, V.; Mathews, N.; Boix, P.P.; Mhaisalkar, S.G. Nanostructuring Mixed-Dimensional Perovskites: A Route Toward Tunable, Efficient Photovoltaics. Adv. Mater. 2016, 28, 3653-3661. [CrossRef] [PubMed]

83. Cao, D.H.; Stoumpos, C.C.; Farha, O.K.; Hupp, J.T.; Kanatzidis, M.G. 2D Homologous Perovskites as Light-Absorbing Materials for Solar Cell Applications. J. Am. Chem. Soc. 2015, 137, 7843-7850. [CrossRef] 
84. Shao, S.; Liu, J.; Portale, G.; Fang, H.-H.; Blake, G.R.; Brink, G.H.T.; Koster, L.J.A.; Loi, M.A. Highly Reproducible Sn-Based Hybrid Perovskite Solar Cells with 9\% Efficiency. Adv. Energy Mater. 2017, 8, 1702019. [CrossRef]

85. Tsai, H.; Nie, W.; Blancon, J.-C.; Stoumpos, C.C.; Asadpour, R.; Harutyunyan, B.; Neukirch, A.J.; Verduzco, R.; Crochet, J.J.; Tretiak, S.; et al. High-efficiency two-dimensional Ruddlesden-Popper perovskite solar cells. Natural 2016, 536, 312-316. [CrossRef] [PubMed]

86. Cruz, S.H.T.; Hagfeldt, A.; Saliba, M. Methylammonium-free, high-performance, and stable perovskite solar cells on a planar architecture. Science 2018, 362, 449-453. [CrossRef] [PubMed]

87. Arora, N.; Dar, M.I.; Hinderhofer, A.; Pellet, N.; Schreiber, F.; Zakeeruddin, S.M.; Grätzel, M. Perovskite solar cells with CuSCN hole extraction layers yield stabilized efficiencies greater than $20 \%$. Science 2017, 358, 768-771. [CrossRef]

88. Hou, Y.; Du, X.; Scheiner, S.; McMeekin, D.P.; Wang, Z.; Li, N.; Killian, M.S.; Chen, H.; Richter, M.; Levchuk, I.; et al. A generic interface to reduce the efficiency-stability-cost gap of perovskite solar cells. Science 2017, 358, 1192-1197. [CrossRef] [PubMed]

89. Chen, C.; Cheng, Y.; Dai, Q.; Song, H. Radio Frequency Magnetron Sputtering Deposition of TiO2 Thin Films and Their Perovskite Solar Cell Applications. Sci. Rep. 2015, 5, 17684. [CrossRef] [PubMed]

90. Fakharuddin, A.; Di Giacomo, F.; Palma, A.L.; Matteocci, F.; Razza, S.; Epifanio, A.D.; Licoccia, S.; Ismail, J.; Carlo, A.D.; Brown, T.M.; et al. Vertical $\mathrm{TiO}_{2}$ Nanorods as a Medium for Durable and High Efficiency Perovskite Solar Modules. Chem. Sci. 2015, 9, 8420-8429. [CrossRef]

91. Qiu, W.; Paetzold, U.W.; Gehlhaar, R.; Smirnov, V.; Boyen, H.-G.; Tait, J.G.; Conings, B.; Zhang, W.; Nielsen, C.B.; McCulloch, I.; et al. An electron beam evaporated $\mathrm{TiO}_{2}$ layer for high efficiency planar perovskite solar cells on flexible polyethylene terephthalate substrates. J. Mater. Chem. A 2015, 3, 22824-22829. [CrossRef]

92. Chen, H.; Yang, S. Carbon-Based Perovskite Solar Cells without Hole Transport Materials: The Front Runner to the Market? Adv. Mater. 2017, 29, 1603994. [CrossRef]

93. Collavini, S.; Delgado, J.L. Carbon Nanoforms in Perovskite-Based Solar Cells. Adv. Energy Mater. 2016, 7, 1601000. [CrossRef]

94. Torabi, N.; Behjat, A.; Zhou, Y.; Docampo, P.; Stoddard, R.J.; Hillhouse, H.W.; Ameri, T. Progress and challenges in perovskite photovoltaics from single- to multi-junction cells. Mater. Today Energy 2019, 12, 70-94. [CrossRef]

95. Barbe, J.M.; Tietze, M.L.; Neophytou, M.; Banavoth, M.; Alarousu, E.; El Labban, A.; Abulikemu, M.; Yue, W.; Mohammed, O.F.; McCulloch, I.; et al. Amorphous Tin Oxide as a Low-Temperature-Processed Electron-Transport Layer for Organic and Hybrid Perovskite Solar Cells. ACS Appl. Mater. Interfaces 2017, 9, 11828-11836. [CrossRef] [PubMed]

96. Anaraki, E.H.; Kermanpur, A.; Steier, L.; Domanski, K.; Matsui, T.; Tress, W.; Saliba, M.; Abate, A.; Grätzel, M.; Hagfeldt, A.; et al. Highly efficient and stable planar perovskite solar cells by solution-processed tin oxide. Energy Environ. Sci. 2016, 9, 3128-3134. [CrossRef]

97. Yu, W.; Li, F.; Wang, H.; Alarousu, E.; Chen, Y.; Ling, Y.; Wang, L.; Hedhili, M.N.; Li, Y.; Wu, K.; et al. Ultrathin $\mathrm{Cu}_{2} \mathrm{O}$ as an efficient inorganic hole transporting material for perovskite solar cells. Nanoscale 2016, 8, 6173-6179. [CrossRef] [PubMed]

98. You, J.; Meng, L.; Song, T.-B.; Guo, T.-F.; Yang, Y.; Chang, W.-H.; Hong, Z.; Chen, H.; Zhou, H.; Chen, Q.; et al. Improved air stability of perovskite solar cells via solution-processed metal oxide transport layers. Nat. Nanotechnol. 2015, 11, 75-81. [CrossRef] [PubMed]

99. Nejand, B.A.; Ahmadi, V.; Shahverdi, H.R. New Physical Deposition Approach for Low Cost Inorganic Hole Transport Layer in Normal Architecture of Durable Perovskite Solar Cells. ACS Appl. Mater. Interfaces 2015, 7, 21807-21818. [CrossRef] [PubMed]

100. Higgins, M.; Ely, F.; Nome, R.C.; Nome, R.A.; Dos Santos, D.P.; Choi, H.; Nam, S.; Quevedo-Lopez, M. Enhanced reproducibility of planar perovskite solar cells by fullerene doping with silver nanoparticles. $J$. Appl. Phys. 2018, 124, e065306. [CrossRef]

101. Li, S.; Zhang, H.; Zhao, W.; Ye, L.; Yao, H.; Yang, B.; Zhang, S.; Hou, J. Green-Solvent-Processed All-Polymer Solar Cells Containing a Perylene Diimide-Based Acceptor with an Efficiency over 6.5\%. Adv. Energy Mater. 2015, 6, e1501991. [CrossRef] 
102. Zheng, H.; Liu, G.; Zhang, C.-N.; Zhu, L.; Alsaedi, A.; Hayat, T.; Pan, X.; Dai, S. The influence of perovskite layer and hole transport material on the temperature stability about perovskite solar cells. Sol. Energy 2018, 159, 914-919. [CrossRef]

103. Ponseca, J.C.S.; Chábera, P.; Uhlig, J.; Persson, P.; Sundström, V. Ultrafast Electron Dynamics in Solar Energy Conversion. Chem. Rev. 2017, 117, 10940-11024. [CrossRef]

104. Bashir, A.; Shukla, S.; Lew, J.H.; Shukla, S.; Bruno, A.; Gupta, D.; Baikie, T.; Patidar, R.; Akhter, Z.; Priyadarshi, A.; et al. Spinel $\mathrm{Co}_{3} \mathrm{O}_{4}$ nanomaterials for efficient and stable large area carbon-based printed perovskite solar cells. Nanoscale 2018, 10, 2341-2350. [CrossRef] [PubMed]

105. Xu, X.; Liu, Z.; Zuo, Z.; Zhang, M.; Zhao, Z.; Shen, Y.; Zhou, H.; Chen, Q.; Yang, Y.; Wang, M.-K. Hole Selective $\mathrm{NiO}$ Contact for Efficient Perovskite Solar Cells with Carbon Electrode. Nano Lett. 2015, 15, 2402-2408. [CrossRef] [PubMed]

106. Hu, R.; Zhang, R.; Ma, Y.; Liu, W.; Chu, L.; Mao, W.; Zhang, J.; Yang, J.; Pu, Y.; Li, X. Enhanced hole transfer in hole-conductor-free perovskite solar cells via incorporating CuS into carbon electrodes. Appl. Surf. Sci. 2018, 462, 840-846. [CrossRef]

107. Ku, Z.; Rong, Y.; Xu, M.; Liu, T.; Han, H. Full Printable Processed Mesoscopic $\mathrm{CH}_{3} \mathrm{NH}_{3} \mathrm{PbI}_{3} / \mathrm{TiO}_{2}$ Heterojunction Solar Cells with Carbon Counter Electrode. Sci. Rep. 2013, 3, 3132. [CrossRef]

108. Liu, S.; Cao, K.; Li, H.; Song, J.; Han, J.; Shen, Y.; Wang, M.-K. Full printable perovskite solar cells based on mesoscopic $\mathrm{TiO}_{2} / \mathrm{Al}_{2} \mathrm{O}_{3} / \mathrm{NiO}$ (carbon nanotubes) architecture. Sol. Energy 2017, 144, 158-165. [CrossRef]

109. Bhandari, S.; Roy, A.; Ghosh, A.; Mallick, T.K.; Sundaram, S. Performance of $\mathrm{WO}_{3}$-Incorporated Carbon Electrodes for Ambient Mesoscopic Perovskite Solar Cells. ACS Omega 2019, 5, 422-429. [CrossRef]

110. Kettle, J. Ready cells for large-scale systems. Nat. Energy 2019, 4, 536-537. [CrossRef]

111. Tress, W.; Domanski, K.; Carlsen, B.; Agarwalla, A.; Alharbi, E.A.; Graetzel, M.; Hagfeldt, A. Performance of perovskite solar cells under simulated temperature-illumination real-world operating conditions. Nat. Energy 2019, 4, 568-574. [CrossRef]

112. Babayigit, A.; Ethirajan, A.; Muller, M.; Conings, B. Toxicity of organometal halide perovskite solar cells. Nat. Mater. 2016, 15, 247-251. [CrossRef]

113. Luceño, J.A.; Pascual, A.M.D.; Capilla, R.P. Materials for Photovoltaics: State of Art and Recent Developments. Int. J. Mol. Sci. 2019, 20, 976. [CrossRef]

114. Hailegnaw, B.; Kirmayer, S.; Edri, E.; Hodes, G.; Cahen, D. Rain on Methylammonium Lead Iodide Based Perovskites: Possible Environmental Effects of Perovskite Solar Cells. J. Phys. Chem. Lett. 2015, 6, 1543-1547. [CrossRef] [PubMed]

115. Li, J.; Cao, H.-L.; Jiao, W.-B.; Wang, Q.; Wei, M.; Cantone, I.; Lü, J.; Abate, A. Biological impact of lead from halide perovskites reveals the risk of introducing a safe threshold. Nat. Commun. 2020, 11, 1-5. [CrossRef]

116. Su, P.; Liu, Y.; Zhang, J.; Chen, C.; Yang, B.; Zhang, C.; Zhao, X. Pb-Based Perovskite Solar Cells and the Underlying Pollution behind Clean Energy: Dynamic Leaching of Toxic Substances from Discarded Perovskite Solar Cells. J. Phys. Chem. Lett. 2020, 11, 2812-2817. [CrossRef]

117. Babayigit, A.; Duy-Thanh, D.; Ethirajan, A.; Manca, J.; Muller, M.; Boyen, H.-G.; Conings, B. Assessing the toxicity of $\mathrm{Pb}$ - and $\mathrm{Sn}$-based perovskite solar cells in model organism Danio rerio. Sci. Rep. 2016, 6, 18721. [CrossRef]

118. Wang, Z.; Fang, J.; Mi, Y.; Zhu, X.; Ren, H.; Liu, X.; Yan, Y. Enhanced performance of perovskite solar cells by ultraviolet-ozone treatment of mesoporous TiO. Appl. Surf. Sci. 2018, 436, 596-602. [CrossRef]

119. Hasan, S.A.U.; Lee, D.S.; Im, S.H.; Hong, K.-H. Present Status and Research Prospects of Tin-based Perovskite Solar Cells. Sol. RRL 2019, 4, 4. [CrossRef]

120. Parida, B.; Yoon, S.; Jeong, S.M.; Cho, J.S.; Kim, J.-K.; Kang, D.-W. Recent progress on cesium lead/tin halide-based inorganic perovskites for stable and efficient solar cells: A review. Sol. Energy Mater. Sol. Cells 2020, 204, 110212. [CrossRef]

121. Sun, Y.-Y.; Agiorgousis, M.L.; Zhang, P.; Zhang, S. Chalcogenide Perovskites for Photovoltaics. Nano Lett. 2015, 15, 581-585. [CrossRef]

122. Khalfin, S.; Bekenstein, Y. Advances in lead-free double perovskite nanocrystals, engineering band-gaps and enhancing stability through composition tunability. Nanoscale 2019, 11, 8665-8679. [CrossRef]

123. Chen, L.-J.; Lee, C.-R.; Chuang, Y.-J.; Wu, Z.-H.; Chen, C. Synthesis and Optical Properties of Lead-Free Cesium Tin Halide Perovskite Quantum Rods with High-Performance Solar Cell Application. J. Phys. Chem. Lett. 2016, 7, 5028-5035. [CrossRef] 
124. Kumar, M.H.; Dharani, S.; Leong, W.L.; Boix, P.P.; Prabhakar, R.R.; Baikie, T.; Shi, C.; Ding, H.; Ramesh, R.; Asta, M.; et al. Lead-Free Halide Perovskite Solar Cells with High Photocurrents Realized Through Vacancy Modulation. Adv. Mater. 2014, 26, 7122-7127. [CrossRef]

125. Chen, M.; Ju, M.-G.; Carl, A.D.; Zong, Y.; Grimm, R.L.; Gu, J.; Zeng, X.C.; Zhou, Y.; Padture, N.P. Cesium Titanium(IV) Bromide Thin Films Based Stable Lead-free Perovskite Solar Cells. Joule 2018, 2, 558-570. [CrossRef]

126. Jiang, X.; Wang, F.; Wei, Q.; Li, H.; Shang, Y.; Zhou, W.; Wang, C.; Cheng, P.; Chen, Q.; Chen, L.; et al. Ultra-high open-circuit voltage of tin perovskite solar cells via an electron transporting layer design. Nat. Commun. 2020, 11, 1-7. [CrossRef]

127. Hao, F.; Stoumpos, C.C.; Cao, D.H.; Chang, R.P.H.; Kanatzidis, M.G. Lead-free solid-state organic-inorganic halide perovskite solar cells. Nat. Photonics 2014, 8, 489-494. [CrossRef]

128. Zhu, Z.; Chueh, C.-C.; Li, N.; Mao, C.; Jen, A.K.-Y. Realizing Efficient Lead-Free Formamidinium Tin Triiodide Perovskite Solar Cells via a Sequential Deposition Route. Adv. Mater. 2017, 30, 1703800. [CrossRef]

129. Nishikubo, R.; Ishida, N.; Katsuki, Y.; Wakamiya, A.; Saeki, A. Minute-Scale Degradation and Shift of Valence-Band Maxima of $\left(\mathrm{CH}_{3} \mathrm{NH}_{3}\right) \mathrm{SnI}_{3}$ and $\mathrm{HC}\left(\mathrm{NH}_{2}\right)_{2} \mathrm{SnI}_{3}$ Perovskites upon Air Exposure. J. Phys. Chem. C 2017, 121, 19650-19656. [CrossRef]

130. Greul, E.; Petrus, M.L.; Binek, A.; Docampo, P.; Bein, T. Highly stable, phase pure $\mathrm{Cs}_{2} \mathrm{AgBiBr}_{6} \mathrm{double}$ perovskite thin films for optoelectronic applications. J. Mater. Chem. A 2017, 5, 19972-19981. [CrossRef]

131. Zhang, Z.; Li, X.; Xia, X.; Wang, Z.; Huang, Z.; Lei, B.; Gao, Y. High-Quality $\left(\mathrm{CH}_{3} \mathrm{NH}_{3}\right)_{3} \mathrm{Bi}_{2} \mathrm{I}_{9}$ Film-Based Solar Cells: Pushing Efficiency up to 1.64\%. J. Phys. Chem. Lett. 2017, 8, 4300-4307. [CrossRef]

132. Nie, R.; Mehta, A.; Park, B.-W.; Kwon, H.-W.; Im, J.; Seok, S.I. Mixed Sulfur and Iodide-Based Lead-Free Perovskite Solar Cells. J. Am. Chem. Soc. 2018, 140, 872-875. [CrossRef]

133. Wei, F.; Deng, Z.; Sun, S.-J.; Xie, F.; Kieslich, G.; Evans, D.M.; A Carpenter, M.; Bristowe, P.D.; Cheetham, A.K. The synthesis, structure and electronic properties of a lead-free hybrid inorganic-organic double perovskite $(\mathrm{MA})_{2} \mathrm{KBiCl}_{6}$ (MA = methylammonium). Mater. Horiz. 2016, 3, 328-332. [CrossRef]

134. Ghosh, A.; Norton, B. Interior colour rendering of daylight transmitted through a suspended particle device switchable glazing. Sol. Energy Mater. Sol. Cells 2017, 163, 218-223. [CrossRef]

135. Ghosh, A.; Norton, B.; Mallick, T.K. Daylight characteristics of a polymer dispersed liquid crystal switchable glazing. Sol. Energy Mater. Sol. Cells 2018, 174, 572-576. [CrossRef]

136. Ghosh, A.; Norton, B.; Mallick, T.K. Influence of atmospheric clearness on PDLC switchable glazing transmission. Energy Build. 2018, 172, 257-264. [CrossRef]

137. Ghosh, A.; Mallick, T. Evaluation of colour properties due to switching behaviour of a PDLC glazing for adaptive building integration. Renew. Energy 2018, 120, 126-133. [CrossRef]

138. Nundy, S.; Ghosh, A. Thermal and visual comfort analysis of adaptive vacuum integrated switchable suspended particle device window for temperate climate. Renew. Energy 2019. [CrossRef]

139. Ghosh, A.; Selvaraj, P.; Sundaram, S.; Mallick, T.K. The colour rendering index and correlated colour temperature of dye-sensitized solar cell for adaptive glazing application. Sol. Energy 2018, 163, 537-544. [CrossRef]

140. Traverse, C.J.; Pandey, R.; Barr, M.C.; Lunt, R.R. Correction: Emergence of highly transparent photovoltaics for distributed applications (Nature Energy (2017) doi:10.1038/s41560-017-0016-9). Nat. Energy 2018, 3, 157. [CrossRef]

141. Yuan, L.; Wang, Z.; Duan, R.; Huang, P.; Zhang, K.; Chen, Q.; Allam, N.K.; Zhou, Y.; Song, B.; Li, Y. Semi-transparent perovskite solar cells: Unveiling the trade-off between transparency and efficiency. J. Mater. Chem. A 2018, 6, 19696-19702. [CrossRef]

142. Jung, J.W.; Chueh, C.-C.; Jen, A.K.-Y. High-Performance Semitransparent Perovskite Solar Cells with $10 \%$ Power Conversion Efficiency and 25\% Average Visible Transmittance Based on Transparent CuSCN as the Hole-Transporting Material. Adv. Energy Mater. 2015, 5, 1500486. [CrossRef]

143. Ghosh, A.; Norton, B.; Duffy, A. Effect of sky conditions on light transmission through a suspended particle device switchable glazing. Sol. Energy Mater. Sol. Cells 2017, 160, 134-140. [CrossRef]

144. Ghosh, A.; Norton, B.; Duffy, A. Effect of atmospheric transmittance on performance of adaptive SPD-vacuum switchable glazing. Sol. Energy Mater. Sol. Cells 2017, 161, 424-431. [CrossRef]

145. Sun, J.; Jasieniak, J. Semi-transparent solar cells. J. Phys. D: Appl. Phys. 2017, 50, 093001. [CrossRef] 
146. Fu, F.; Feurer, T.; Weiss, T.P.; Pisoni, S.; Avancini, E.; Andres, C.; Buecheler, S.; Tiwari, A.N. High-efficiency inverted semi-transparent planar perovskite solar cells in substrate configuration. Nat. Energy 2016, 2, 16190. [CrossRef]

147. Novak, S.; Hillebrandt, M. Analysing the trade-off between transparency and efficiency in the Council of the European Union. J. Eur. Public Policy 2019, 27, 141-159. [CrossRef]

148. Shin, D.; Choi, S.-H. Recent Studies of Semitransparent Solar Cells. Coatings 2018, 8, 329. [CrossRef]

149. Ghosh, A.; Sarmah, N.; Sundaram, S.; Mallick, T.K. Numerical studies of thermal comfort for semi-transparent building integrated photovoltaic (BIPV)-vacuum glazing system. Sol. Energy 2019, 190, 608-616. [CrossRef]

150. Roy, A.; Bhandari, S.; Ghosh, A.; Sundaram, S.; Mallick, T.K. Incorporating Solution-Processed Mesoporous WO3 as an Interfacial Cathode Buffer Layer for Photovoltaic Applications. J. Phys. Chem. A 2020. [CrossRef]

151. Kwon, H.-C.; Moon, J. Recent advances in high-performance semitransparent perovskite solar cells. Curr. Opin. Electrochem. 2018, 11, 114-121. [CrossRef]

152. Husain, A.A.; Hasan, W.Z.W.; Shafie, S.; Hamidon, M.N.; Pandey, S.S. A review of transparent solar photovoltaic technologies. Renew. Sustain. Energy Rev. 2018, 94, 779-791. [CrossRef]

153. Shi, B.; Duan, L.; Zhao, Y.; Luo, J.; Zhang, X. Semitransparent Perovskite Solar Cells: From Materials and Devices to Applications. Adv. Mater. 2019, 32, e1806474. [CrossRef]

154. Leijtens, T.; Lauber, B.; Eperon, G.E.; Stranks, S.D.; Snaith, H.J. The Importance of Perovskite Pore Filling in Organometal Mixed Halide Sensitized $\mathrm{TiO}_{2}$-Based Solar Cells. J. Phys. Chem. Lett. 2014, 5, 1096-1102. [CrossRef]

155. Stranks, S.D.; Eperon, G.E.; Grancini, G.; Menelaou, C.; Alcocer, M.; Leijtens, T.; Herz, L.M.; Petrozza, A.; Snaith, H.J. Electron-Hole Diffusion Lengths Exceeding 1 Micrometer in an Organometal Trihalide Perovskite Absorber. Science 2013, 342, 341-344. [CrossRef] [PubMed]

156. Malinkiewicz, O.; Yella, A.; Lee, Y.H.; Espallargas, G.M.; Graetzel, M.; Nazeeruddin, M.K.; Bolink, H.J. Perovskite solar cells employing organic charge-transport layers. Nat. Photonics 2013, 8, 128-132. [CrossRef]

157. Liu, D.; Kelly, T.L. Perovskite solar cells with a planar heterojunction structure prepared using room-temperature solution processing techniques. Nat. Photonics 2013, 8, 133-138. [CrossRef]

158. Eperon, G.E.; Burlakov, V.M.; Docampo, P.; Goriely, A.; Snaith, H.J. Morphological Control for High Performance, Solution-Processed Planar Heterojunction Perovskite Solar Cells. Adv. Funct. Mater. 2013, 24, 151-157. [CrossRef]

159. Eperon, G.E.; Burlakov, V.M.; Goriely, A.; Snaith, H.J. Neutral Color Semitransparent Microstructured Perovskite Solar Cells. ACS Nano 2013, 8, 591-598. [CrossRef]

160. Hörantner, M.T.; Nayak, P.K.; Mukhopadhyay, S.; Wojciechowski, K.; Beck, C.; McMeekin, D.; Kamino, B.; Eperon, G.E.; Snaith, H.J. Shunt-Blocking Layers for Semitransparent Perovskite Solar Cells. Adv. Mater. Interfaces 2016, 3, 1500837. [CrossRef]

161. Burlakov, V.M.; Eperon, G.E.; Snaith, H.J.; Chapman, S.J.; Goriely, A. Controlling coverage of solution cast materials with unfavourable surface interactions. Appl. Phys. Lett. 2014, 104, 091602. [CrossRef]

162. Xiao, Y.; Han, G.; Chang, Y.; Zhang, Y.; Li, Y.; Li, M. Investigation of perovskite-sensitized nanoporous titanium dioxide photoanodes with different thicknesses in perovskite solar cells. J. Power Sources 2015, 286, 118-123. [CrossRef]

163. Heo, J.H.; Jang, M.H.; Lee, M.H.; Han, H.J.; Kang, M.G.; Lee, M.L.; Im, S.H. Efficiency enhancement of semi-transparent sandwich type $\mathrm{CH}_{3} \mathrm{NH}_{3} \mathrm{PbI}_{3}$ perovskite solar cells with island morphology perovskite film by introduction of polystyrene passivation layer. J. Mater. Chem. A 2016, 4, 16324-16329. [CrossRef]

164. Dou, L.; You, J.; Hong, Z.; Xu, Z.; Li, G.; Street, R.A.; Yang, Y. 25th Anniversary Article: A Decade of Organic/Polymeric Photovoltaic Research. Adv. Mater. 2013, 25, 6642-6671. [CrossRef]

165. Bailie, C.; Christoforo, G.; Mailoa, J.P.; Bowring, A.R.; Unger, E.L.; Nguyen, W.H.; Burschka, J.; Pellet, N.; Lee, J.Z.; Grätzel, M.; et al. Semi-transparent perovskite solar cells for tandems with silicon and CIGS. Energy Environ. Sci. 2015, 8, 956-963. [CrossRef]

166. Fu, F.; Feurer, T.; Jäger, T.; Avancini, E.; Bissig, B.; Yoon, S.; Buecheler, S.; Tiwari, A.N. Low-temperature-processed efficient semi-transparent planar perovskite solar cells for bifacial and tandem applications. Nat. Commun. 2015, 6, 8932. [CrossRef] [PubMed]

167. Rai, M.; Rahmany, S.; Lim, S.S.; Magdassi, S.; Wong, L.H.; Etgar, L. Hot dipping post treatment for improved efficiency in micro patterned semi-transparent perovskite solar cells. J. Mater. Chem. A 2018, 6, 23787-23796. [CrossRef] 
168. Tong, J.; Song, Z.; Kim, D.H.; Chen, X.; Chen, C.; Palmstrom, A.F.; Ndione, P.F.; Reese, M.O.; Dunfield, S.P.; Reid, O.G.; et al. Carrier lifetimes of $>1 \mu \mathrm{s}$ in $\mathrm{Sn}-\mathrm{Pb}$ perovskites enable efficient all-perovskite tandem solar cells. Science 2019, 364, 475-479. [CrossRef] [PubMed]

169. Guo, Y.; Shoyama, K.; Sato, W.; Nakamura, E. Polymer Stabilization of Lead(II) Perovskite Cubic Nanocrystals for Semitransparent Solar Cells. Adv. Energy Mater. 2016, 6, 1502317. [CrossRef]

170. Della Gaspera, E.; Peng, Y.; Hou, Q.; Spiccia, L.; Bach, U.; Jasieniak, J.; Cheng, Y.-B. Ultra-thin high efficiency semitransparent perovskite solar cells. Nano Energy 2015, 13, 249-257. [CrossRef]

171. Kwon, H.-C.; Kim, A.; Lee, H.; Lee, D.; Jeong, S.; Moon, J. Parallelized Nanopillar Perovskites for Semitransparent Solar Cells Using an Anodized Aluminum Oxide Scaffold. Adv. Energy Mater. 2016, 6, 1601055. [CrossRef]

172. Heo, J.H.; Han, H.J.; Lee, M.; Song, M.; Kim, D.-H.; Im, S.H. Stable semi-transparent CH3NH3PbI3planar sandwich solar cells. Energy Environ. Sci. 2015, 8, 2922-2927. [CrossRef]

173. Zhao, J.; Brinkmann, K.O.; Hu, T.; Pourdavoud, N.; Becker, T.; Gahlmann, T.; Heiderhoff, R.; Polywka, A.; Görrn, P.; Chen, Y.; et al. Self-Encapsulating Thermostable and Air-Resilient Semitransparent Perovskite Solar Cells. Adv. Energy Mater. 2017, 7, 1602599. [CrossRef]

174. Li, F.R.; Xu, Y.; Chen, W.; Xie, S.; Li, J. Nanotube enhanced carbon grids as top electrodes for fully printable mesoscopic semitransparent perovskite solar cells. J. Mater. Chem. A 2017, 5, 10374-10379. [CrossRef]

175. Chen, W.; Zhang, J.; Xu, G.; Xue, R.; Li, Y.; Zhou, Y.; Hou, J.; Li, Y. A Semitransparent Inorganic Perovskite Film for Overcoming Ultraviolet Light Instability of Organic Solar Cells and Achieving 14.03\% Efficiency. Adv. Mater. 2018, 30, 1-10. [CrossRef] [PubMed]

176. Wheeler, L.M.; Moore, D.T.; Ihly, R.; Stanton, N.J.; Miller, E.M.; Tenent, R.C.; Blackburn, J.L.; Neale, N.R. Switchable photovoltaic windows enabled by reversible photothermal complex dissociation from methylammonium lead iodide. Nat. Commun. 2017, 8, 1722. [CrossRef] [PubMed]

177. Duong, T.; Wu, Y.; Shen, H.; Peng, J.; Fu, X.; Jacobs, D.; Wang, E.-C.; Kho, T.C.; Fong, K.C.; Stocks, M.; et al. Rubidium Multication Perovskite with Optimized Bandgap for Perovskite-Silicon Tandem with over $26 \%$ Efficiency. Adv. Energy Mater. 2017, 7, 1700228. [CrossRef]

178. Bush, K.; Palmstrom, A.F.; Yu, Z.J.; Boccard, M.; Cheacharoen, R.; Mailoa, J.P.; McMeekin, D.P.; Hoye, R.L.; Bailie, C.D.; Leijtens, T.; et al. 23.6\%-efficient monolithic perovskite/silicon tandem solar cells with improved stability. Nat. Energy 2017, 2, 17009. [CrossRef]

179. Roldán-Carmona, C.; Malinkiewicz, O.; Betancur, R.; Longo, G.; Momblona, C.; Jaramillo, F.; Camacho, L.; Bolink, H.J. High efficiency single-junction semitransparent perovskite solar cells. Energy Environ. Sci. 2014, 7, 2968-2973. [CrossRef]

180. Lu, J.-H.; Yu, Y.-L.; Chuang, S.-R.; Yeh, C.-H.; Chen, C.P. High-Performance, Semitransparent, Easily Tunable Vivid Colorful Perovskite Photovoltaics Featuring Ag/ITO/Ag Microcavity Structures. J. Phys. Chem. C 2016, 120, 4233-4239. [CrossRef]

181. Lee, K.T.; Jang, J.-Y.; Park, S.J.; Ok, S.A.; Park, H.J. Incident-angle-controlled semitransparent colored perovskite solar cells with improved efficiency exploiting a multilayer dielectric mirror. Nanoscale 2017, 9, 13983-13989. [CrossRef]

182. Jiang, Y.; Luo, B.; Jiang, F.; Jiang, F.; Fuentes-Hernandez, C.; Liu, T.; Mao, L.; Xiong, S.; Li, Z.; Wang, T.; et al. Efficient Colorful Perovskite Solar Cells Using a Top Polymer Electrode Simultaneously as Spectrally Selective Antireflection Coating. Nano Lett. 2016, 16, 7829-7835. [CrossRef]

183. Kim, H.; Kim, H.-S.; Ha, J.; Yoo, S.; Park, N.-G. Empowering Semi-Transparent Solar Cells with Thermal-Mirror Functionality. Adv. Energy Mater. 2016, 6, 1502466. [CrossRef]

184. Ghosh, A.; Bhandari, S.; Sundaram, S.; Mallick, T.K. Carbon counter electrode mesoscopic ambient processed \& characterised perovskite for adaptive BIPV fenestration. Renew. Energy 2020, 145, 2151-2158. [CrossRef]

185. Bhandari, S.; Roy, A.; Mallick, T.K.; Sundaram, S. Impact of different light induced effect on organic hole-transporting layer in perovskite solar cells. Mater. Lett. 2020, 268, 127568. [CrossRef]

186. Yang, M.; Zhou, Y.; Zeng, Y.; Jiang, C.-S.; Padture, N.P.; Zhu, K. Square-Centimeter Solution-Processed Planar $\mathrm{CH}_{3} \mathrm{NH}_{3} \mathrm{PbI}_{3}$ Perovskite Solar Cells with Efficiency Exceeding 15\%. Adv. Mater. 2015, 27, 6363-6370. [CrossRef] [PubMed]

187. Razza, S.; Hermosa, S.A.C.; Di Carlo, A.; Brown, T.M. Research Update: Large-area deposition, coating, printing, and processing techniques for the upscaling of perovskite solar cell technology. APL Mater. 2016, 4, 091508. [CrossRef] 
188. Rossi, L.M.; Fiorio, J.L.; Garcia, M.A.S.; Ferraz, C.P. The role and fate of capping ligands in colloidally prepared metal nanoparticle catalysts. Dalton Trans. 2018, 47, 5889-5915. [CrossRef] [PubMed]

189. Gardner, K.L.; Tait, J.G.; Merckx, T.; Qiu, W.; Paetzold, U.W.; Kootstra, L.; Jaysankar, M.; Gehlhaar, R.; Cheyns, D.; Heremans, P.; et al. Nonhazardous Solvent Systems for Processing Perovskite Photovoltaics. Adv. Energy Mater. 2016, 6, 1600386. [CrossRef]

190. Hu, Y.; Si, S.; Mei, A.; Rong, Y.; Liu, H.; Li, X.; Han, H. Stable Large-Area $\left(10 \times 10 \mathrm{~cm}^{2}\right)$ Printable Mesoscopic Perovskite Module Exceeding 10\% Efficiency. Sol. RRL 2017, 1, 1600019. [CrossRef]

191. Cai, L.; Liang, L.; Wu, J.; Ding, B.; Gao, L.; Fan, B. Large area perovskite solar cell module. J. Semicond. 2017, 38, 14006. [CrossRef]

192. Corporation, N.T. NEDO and Toshiba Develops World's Largest Film-Based Perovskite Photovoltaic Module-703 cm $\mathrm{cm}^{2}$ Module Achieves 11.7\% Power Conversion Efficiency. Available online: https://www. nedo.go.jp/english/news/AA5en_100391.html (accessed on 4 May 2020).

193. Microquanta. Microquanta Semiconductor; Microquanta: Hangzhou, China, 2019.

194. Bellini, E. PANASONIC Claims 16.09\% Efficiency for Lightweight Perovskite Solar Module. Available online: https://www.pv-magazine.com/2020/01/21/panasonic-claims-16-1-efficiency-for-lightweight-perovskitesolar-module/ (accessed on 3 May 2020).

195. Wang, H.; Dewi, H.A.; Koh, T.M.; Bruno, A.; Mhaisalkar, S.G.; Mathews, N. Bifacial, Color-Tunable Semitransparent Perovskite Solar Cells for Building-Integrated Photovoltaics. ACS Appl. Mater. Interfaces 2019, 12, 484-493. [CrossRef] [PubMed]

196. Aernouts, T. Efficient Structures and Processes for Reliable Perovskite Solar Modules. In Proceedings of the International Conference on Hybrid and Organic Photovoltaics, Roma, Italy, 12-15 May 2019.

197. Zhang, W.; Anaya, M.; Lozano, G.; Calvo, M.E.; Johnston, M.B.; Míguez, H.; Snaith, H.J. Highly Efficient Perovskite Solar Cells with Tunable Structural Color. Nano Lett. 2015, 15, 1698-1702. [CrossRef]

198. Lin, J.; Lai, M.; Dou, L.; Kley, C.S.; Chen, H.; Peng, F.; Sun, J.; Lu, D.; Hawks, S.A.; Xie, C.; et al. Thermochromic halide perovskite solar cells. Nat. Mater. 2018, 17, 261-267. [CrossRef] [PubMed]

199. Martellotta, F.; Cannavale, A.; Ayr, U. Comparing energy performance of different semi-transparent, building-integrated photovoltaic cells applied to "reference" buildings. Energy Procedia 2017, 126, 219-226. [CrossRef]

200. Shen, H.; Duong, T.; Peng, J.; Jacobs, D.; Wu, N.; Gong, J.; Wu, Y.; Karuturi, S.K.; Fu, X.; Weber, K.; et al. Mechanically-stacked perovskite/CIGS tandem solar cells with efficiency of $23.9 \%$ and reduced oxygen sensitivity. Energy Environ. Sci. 2018, 11, 394-406. [CrossRef]

201. Shen, G.; Du, Z.; Pan, Z.; Du, J.; Zhong, X. Solar Paint from $\mathrm{TiO}_{2}$ Particles Supported Quantum Dots for Photoanodes in Quantum Dot-Sensitized Solar Cells. ACS Omega 2018, 3, 1102-1109. [CrossRef] [PubMed]

202. Skanska. Skanska Launches First Perovskite Solar Cell Application In Office Buildings Together with Saule Technologies. Available online: https://www.linkedin.com/feed/update/urn:li:activity:6537688750716182528 (accessed on 1 May 2020).

203. Jung, H.S.; Han, G.S.; Park, N.-G.; Ko, M.J. Flexible Perovskite Solar Cells. Joule 2019, 3, 1850-1880. [CrossRef]

204. Heo, J.H.; Lee, D.S.; Shin, D.H.; Im, S.H. Recent advancements in and perspectives on flexible hybrid perovskite solar cells. J. Mater. Chem. A 2019, 7, 888-900. [CrossRef]

205. Kang, S.; Jeong, J.; Cho, S.; Yoon, Y.J.; Park, S.; Lim, S.; Kim, J.Y.; Ko, H.; Lee, S. Ultrathin, lightweight and flexible perovskite solar cells with an excellent power-per-weight performance. J. Mater. Chem. A 2019, 7, 1107-1114. [CrossRef]

206. Kaltenbrunner, M.; Adam, G.; Głowacki, E.D.; Drack, M.; Schwödiauer, R.; Leonat, L.; Apaydin, D.H.; Groiss, H.; Scharber, M.C.; White, M.; et al. Flexible high power-per-weight perovskite solar cells with chromium oxide-metal contacts for improved stability in air. Nat. Mater. 2015, 14, 1032-1039. [CrossRef]

207. Liu, Z.; Qiu, L.; Juarez-Perez, E.J.; Hawash, Z.; Kim, T.; Jiang, Y.; Wu, Z.; Raga, S.R.; Ono, L.K.; Liu, S. (Frank); et al. Gas-solid reaction based over one-micrometer thick stable perovskite films for efficient solar cells and modules. Nat. Commun. 2018, 9, 3880. [CrossRef]

208. Li, Y.; Meng, L.; Yang, Y.; Xu, G.; Hong, Z.; Chen, Q.; You, J.; Li, G.; Yang, Y.; Li, Y. High-efficiency robust perovskite solar cells on ultrathin flexible substrates. Nat. Commun. 2016, 7, 10214. [CrossRef]

209. Zhang, H.; Cheng, J.; Li, D.; Lin, F.; Mao, J.; Liang, C.; Jen, A.K.-Y.; Grätzel, M.; Choy, W.C.H. Toward All Room-Temperature, Solution-Processed, High-Performance Planar Perovskite Solar Cells: A New Scheme of Pyridine-Promoted Perovskite Formation. Adv. Mater. 2017, 29, 1604695. [CrossRef] [PubMed] 
210. Xie, M.; Wang, J.; Kang, J.; Zhang, L.; Sun, X.; Han, K.; Luo, Q.; Lin, J.; Shi, L.; Ma, C.-Q. Super-flexible perovskite solar cells with high power-per-weight on $17 \mu \mathrm{m}$ thick PET substrate utilizing printed Ag nanowires bottom and top electrodes. Flex. Print. Electron. 2019, 4, 034002. [CrossRef]

211. Khan, S.A.; Rahman, A. Efficiency of thin film photovoltaic paint: A brief review. Int. J. Recent Technol. Eng. 2019, 7, 163-169.

212. Kim, S.-S.; Na, S.-I.; Jo, J.; Tae, G.; Kim, D.-Y. Efficient Polymer Solar Cells Fabricated by Simple Brush Painting. Adv. Mater. 2007, 19, 4410-4415. [CrossRef]

213. Burkitt, D.; Swartwout, R.; McGettrick, J.; Greenwood, P.; Beynon, D.; Brenes, R.; Bulović, V.; Watson, T. Acetonitrile based single step slot-die compatible perovskite ink for flexible photovoltaics. RSC Adv. 2019, 9, 37415-37423. [CrossRef]

214. Mohammad, A.A.; AlKhaldi, K.H.; AlTuwaim, M.S.; Al-Jimaz, A.S. Effect of temperature and chain length on the viscosity and surface tension of binary systems of $N, N$-dimethylformamide with 1-octanol, 1-nonanol and 1-decanol. J. Chem. Thermodyn. 2014, 74, 7-15. [CrossRef]

215. Henni, A.; Hromek, J.J.; Tontiwachwuthikul, P.; Chakma, A. Volumetric Properties and Viscosities for AqueousN-Methyl-2-pyrrolidone Solutions from $25{ }^{\circ} \mathrm{C}$ to $70{ }^{\circ} \mathrm{C}$. J. Chem. Eng. Data 2004, 49, 231-234. [CrossRef]

216. Giuri, A.; Masi, S.; Listorti, A.; Gigli, G.; Colella, S.; Corcione, C.E.; Rizzo, A. Polymeric rheology modifier allows single-step coating of perovskite ink for highly efficient and stable solar cells. Nano Energy 2018, 54, 400-408. [CrossRef]

217. De Bastiani, M.; Saidaminov, M.I.; Dursun, I.; Sinatra, L.; Peng, W.; Buttner, U.; Mohammed, O.F.; Bakr, O.M. Thermochromic Perovskite Inks for Reversible Smart Window Applications. Chem. Mater. 2017, 29, 3367-3370. [CrossRef]

218. Su, J.; Cai, H.; Yang, J.; Ye, X.; Han, R.; Ni, J.; Li, J.; Zhang, J. Perovskite Ink with an Ultrawide Processing Window for Efficient and Scalable Perovskite Solar Cells in Ambient Air. ACS Appl. Mater. Interfaces 2019, 12, 3531-3538. [CrossRef]

219. Park, N.-G.; Segawa, H. Research Direction toward Theoretical Efficiency in Perovskite Solar Cells. ACS Photonics 2018, 5, 2970-2977. [CrossRef]

220. Xiao, Z.; Yan, Y. Progress in Theoretical Study of Metal Halide Perovskite Solar Cell Materials. Adv. Energy Mater. 2017, 7, 1701136. [CrossRef]

221. Stranks, S.D.; Plochocka, P. The influence of the Rashba effect. Nat. Mater. 2018, 17, 381-382. [CrossRef]

222. Butler, K.T.; Frost, J.M.; Walsh, A. Ferroelectric materials for solar energy conversion: Photoferroics revisited. Energy Environ. Sci. 2015, 8, 838-848. [CrossRef]

223. Zhu, C.; Niu, X.; Fu, Y.; Li, N.; Hu, C.; Chen, Y.; He, X.; Na, G.; Liu, P.; Zai, H.; et al. Strain engineering in perovskite solar cells and its impacts on carrier dynamics. Nat. Commun. 2019, 10, 815. [CrossRef] [PubMed]

224. Busipalli, D.L.; Nachimuthu, S.; Jiang, J.-C. Theoretical study on halide and mixed halide Perovskite solar cells: Effects of halide atoms on the stability and electronic properties. J. Chin. Chem. Soc. 2019, 66, 575-582. [CrossRef]

225. Marszal-Pomianowska, A.; Heiselberg, P.; Bourrelle, J.S.; Musall, E.; Voss, K.; Sartori, I.; Napolitano, A. Zero Energy Building-A review of definitions and calculation methodologies. Energy Build. 2011, 43, 971-979. [CrossRef]

226. Walker, L.; Hofer, J.; Schlueter, A. High-resolution, parametric BIPV and electrical systems modeling and design. Appl. Energy 2019, 238, 164-179. [CrossRef]

227. Assoa, Y.B.; Mongibello, L.; Carr, A.; Kubicek, B.; Machado, M.; Merten, J.; Misara, S.; Roca, F.; Sprenger, W.; Wagner, M.; et al. Thermal analysis of a BIPV system by various modelling approaches. Sol. Energy 2017, 155, 1289-1299. [CrossRef]

228. Chakkaravarthy, A.N.; Subathra, M.S.P.; Pradeep, P.J.; Kumar, N.M. Solar irradiance forecasting and energy optimization for achieving nearly net zero energy building. J. Renew. Sustain. Energy 2018, 10, 035103. [CrossRef]

229. Poulek, V.; Matuska, T.; Libra, M.; Kachalouski, E.; Sedláček, J. Influence of increased temperature on energy production of roof integrated PV panels. Energy Build. 2018, 166, 418-425. [CrossRef]

230. Sprenger, W.; Wilson, H.R.; Kuhn, T.E. Electricity yield simulation for the building-integrated photovoltaic system installed in the main building roof of the Fraunhofer Institute for Solar Energy Systems ISE. Sol. Energy 2016, 135, 633-643. [CrossRef] 
231. Gong, X.; Chen, Y.; Liang, M. Theoretical study of building-integrated photovoltaics based on perovskite single junction and perovskite/silicon tandem solar cells. Energy Explor. Exploit. 2019, 38, 723-732. [CrossRef]

232. Meng, L.; You, J.; Yang, Y. Addressing the stability issue of perovskite solar cells for commercial applications. Nat. Commun. 2018, 9, 5265. [CrossRef] [PubMed]

233. Song, Z.; McElvany, C.L.; Phillips, A.B.; Celik, I.; Krantz, P.W.; Watthage, S.C.; Liyanage, G.K.; Apul, D.; Heben, M.J. A technoeconomic analysis of perovskite solar module manufacturing with low-cost materials and techniques. Energy Environ. Sci. 2017, 10, 1297-1305. [CrossRef]

234. Ghosh, A.; Norton, B.; Duffy, A. Conceptualization of a Photovoltaic Powered Electrochromic Switching of a Multifunctional Glazing. In Proceedings of the ISES Solar Energy Congress, Cancun, Mexico, 3-7 November 2013.

235. Ghosh, A.; Norton, B.; Duffy, A. Multifunctional Glazing System-Solution for Modern Smart Glazing Multifunctional Glazing System: Solution for Modern Smart Glazing. In Proceedings of the Passive Low Energy Architecture, Ahemdabad, India, 16-18 December 2014.

236. Ghosh, A.; Norton, B.; Duffy, A. Daylighting performance and glare calculation of a suspended particle device switchable glazing. Sol. Energy 2016, 132, 114-128. [CrossRef]

237. Ghosh, A.; Mallick, T. Evaluation of optical properties and protection factors of a PDLC switchable glazing for low energy building integration. Sol. Energy Mater. Sol. Cells 2018, 176, 391-396. [CrossRef]

238. Xu, X.; Li, S.; Zhang, H.; Shen, Y.; Zakeeruddin, S.M.; Graetzel, M.; Cheng, Y.-B.; Wang, M.-K. A Power Pack Based on Organometallic Perovskite Solar Cell and Supercapacitor. ACS Nano 2015, 9, 1782-1787. [CrossRef]

239. Li, C.; Islam, M.; Moore, J.; Sleppy, J.; Morrison, C.; Konstantinov, K.; Dou, S.X.; Renduchintala, C.; Thomas, J. Wearable energy-smart ribbons for synchronous energy harvest and storage. Nat. Commun. 2016, 7, 13319. [CrossRef] [PubMed]

240. Gao, K.; Ti, D.; Zhang, Z. A photocapacitor with high working voltage and energy density. Sustain. Energy Fuels 2019, 3, 1937-1942. [CrossRef]

241. Zhou, F.; Ren, Z.; Zhao, Y.; Shen, X.; Wang, A.; Li, Y.Y.; Surya, C.; Chai, Y. Perovskite Photovoltachromic Supercapacitor with All-Transparent Electrodes. ACS Nano 2016, 10, 5900-5908. [CrossRef] [PubMed]

242. Zhang, F.; Li, W.; Xu, Z.; Ye, M.; Xu, H.; Guo, W.; Liu, X. Highly flexible and scalable photo-rechargeable power unit based on symmetrical nanotube arrays. Nano Energy 2018, 46, 168-175. [CrossRef]

243. Li, C.; Cong, S.; Tian, Z.; Song, Y.; Yu, L.; Lu, C.; Shao, Y.; Li, J.; Zou, G.; Rümmeli, M.H.; et al. Flexible perovskite solar cell-driven photo-rechargeable lithium-ion capacitor for self-powered wearable strain sensors. Nano Energy 2019, 60, 247-256. [CrossRef]

244. Ahmad, S.; George, C.; Beesley, D.J.; Baumberg, J.J.; De Volder, M. Photo-Rechargeable Organo-Halide Perovskite Batteries. Nano Lett. 2018, 18, 1856-1862. [CrossRef]

245. Xu, J.; Chen, Y.; Dai, L. Efficiently photo-charging lithium-ion battery by perovskite solar cell. Nat. Commun. 2015, 6, 8103. [CrossRef]

246. Gurung, A.; Chen, K.; Khan, R.; Abdulkarim, S.S.; Varnekar, G.; Pathak, R.; Naderi, R.; Qiao, Q. Highly Efficient Perovskite Solar Cell Photocharging of Lithium Ion Battery Using DC-DC Booster. Adv. Energy Mater. 2017, 7, 1602105. [CrossRef]

247. Kin, L.-C.; Liu, Z.; Astakhov, O.; Agbo, S.N.; Tempel, H.; Yu, S.; Kungl, H.; Eichel, R.-A.; Rau, U.; Kirchartz, T.; et al. Efficient Area Matched Converter Aided Solar Charging of Lithium Ion Batteries Using High Voltage Perovskite Solar Cells. ACS Appl. Energy Mater. 2019, 3, 431-439. [CrossRef]

248. Rong, Y.; Hu, Y.; Mei, A.; Tan, H.; Saidaminov, M.I.; Seok, S.I.; McGehee, M.D.; Sargent, E.H.; Han, H. Challenges for commercializing perovskite solar cells. Science 2018, 361, eaat8235. [CrossRef]

249. Wojciechowski, K.; Forgacs, D.; Rivera, T. Industrial Opportunities and Challenges for Perovskite Photovoltaic Technology. Sol. RRL 2019, 3. [CrossRef]

250. Reese, M.O.; Glynn, S.; Kempe, M.; McGott, D.L.; Dabney, M.S.; Barnes, T.M.; Booth, S.; Feldman, D.; Haegel, N.M. Increasing markets and decreasing package weight for high-specific-power photovoltaics. Nat. Energy 2018, 3, 1002-1012. [CrossRef]

251. Grancini, G.; Roldán-Carmona, C.; Zimmermann, I.; Mosconi, E.; Lee, X.; Martineau, D.; Narbey, S.; Oswald, F.; De Angelis, F.; Graetzel, M.; et al. One-Year stable perovskite solar cells by 2D/3D interface engineering. Nat. Commun. 2017, 8, 15684. [CrossRef] 
252. Saifullah, M.; Gwak, J.; Yun, J.H. Comprehensive review on material requirements, present status, and future prospects for building-integrated semitransparent photovoltaics (BISTPV). J. Mater. Chem. A 2016, 4, 8512-8540. [CrossRef]

253. Gullbrekken, L.; Kvande, T.; Time, B. Roof-integrated PV in Nordic Climate—Building Physical Challenges. Energy Procedia 2015, 78, 1962-1967. [CrossRef]

254. Agathokleous, R.A.; Kalogirou, S.A. Status, barriers and perspectives of building integrated photovoltaic systems. Energy 2020, 191, 116471. [CrossRef]

255. Yang, R. Overcoming technical barriers and risks in the application of building integrated photovoltaics (BIPV): Hardware and software strategies. Autom. Constr. 2015, 51, 92-102. [CrossRef]

256. Yang, R.; Zou, P. Building integrated photovoltaics (BIPV): Costs, benefits, risks, barriers and improvement strategy. Int. J. Constr. Manag. 2015, 16, 1-15. [CrossRef]

257. Smestad, G.P.; Germer, T.A.; AlRashidi, H.; Fernández, E.F.; Dey, S.; Brahma, H.; Sarmah, N.; Ghosh, A.; Sellami, N.; Hassan, I.A.I.; et al. Modelling photovoltaic soiling losses through optical characterization. Sci. Rep. 2020, 10, 1-13. [CrossRef]

258. Chanchangi, Y.N.; Ghosh, A.; Sundaram, S.; Mallick, T.K. Dust and PV Performance in Nigeria: A review. Renew. Sustain. Energy Rev. 2020, 121, 109704. [CrossRef]

259. Chanchangi, Y.N.; Ghosh, A.; Sundaram, S.; Mallick, T.K. An analytical indoor experimental study on the effect of soiling on PV, focusing on dust properties and PV surface material. Sol. Energy 2020, 203, 46-68. [CrossRef]

260. Nundy, S.; Ghosh, A.; Mallick, T.K. Hydrophilic and Superhydrophilic Self-Cleaning Coatings by Morphologically Varying ZnO Microstructures for Photovoltaic and Glazing Applications. ACS Omega 2020, 5, 1033-1039. [CrossRef]

261. Hemaida, A.; Ghosh, A.; Sundaram, S.; Mallick, T.K. Evaluation of thermal performance for a smart switchable adaptive polymer dispersed liquid crystal (PDLC) glazing. Sol. Energy 2020, 195, 185-193. [CrossRef]

262. Ghosh, A. Soiling Losses: A Barrier for India's Energy Security Dependency from Photovoltaic Power. Challenges 2020, 11, 9. [CrossRef]

263. Ghosh, A. Possibilities and Challenges for the Inclusion of the Electric Vehicle (EV) to Reduce the Carbon Footprint in the Transport Sector: A Review. Energies 2020, 13, 2602. [CrossRef]

264. Cancelliere, P.; Manzini, G.; Traina, G.; Cavriani, M.G. PV modules on buildings-Outlines of PV roof samples fire rating assessment. Fire Saf. J. 2020, 103139. [CrossRef]

265. Manzini, G.; Gramazio, P.; Guastella, S.; Liciotti, C.; Baffoni, G.L. The Fire Risk in Photovoltaic Installations-Test Protocols for Fire Behavior of PV Modules. Energy Procedia 2015, 82, 752-758. [CrossRef]

266. Snaith, H.J. Present status and future prospects of perovskite photovoltaics. Nat. Mater. 2018, 17, 372-376. [CrossRef]

267. European Council. Restriction of Hazardous Substances in Electrical and Electronic Equipment. European Union. 2003. Available online: https://eur-lex.europa.eu/LexUriServ/LexUriServ.do?uri=CELEX:32002L00 (accessed on 1 June 2020).

268. Cannavale, A.; Martellotta, F. Smart Perovskite-Based Technologies for Building Integration; Elsevier BV: Amsterdam, The Netherlands, 2019; pp. 441-466.

269. Cannavale, A.; Ierardi, L.; Hörantner, M.; Eperon, G.E.; Snaith, H.J.; Ayr, U.; Martellotta, F. Improving energy and visual performance in offices using building integrated perovskite-based solar cells: A case study in Southern Italy. Appl. Energy 2017, 205, 834-846. [CrossRef]

270. Cannavale, A.; Hörantner, M.; Eperon, G.E.; Snaith, H.J.; Fiorito, F.; Ayr, U.; Martellotta, F. Building integration of semitransparent perovskite-based solar cells: Energy performance and visual comfort. Appl. Energy 2017, 194, 94-107. [CrossRef]

(C) 2020 by the authors. Licensee MDPI, Basel, Switzerland. This article is an open access article distributed under the terms and conditions of the Creative Commons Attribution (CC BY) license (http://creativecommons.org/licenses/by/4.0/). 